\title{
Effects of the shed skin aqueous extract of the non- poisonous snake, Ptyas mucosus (Linnaeus, 1758) on the development of the ovotestis of Onchidium tigrinum (Stoliczka 1869) (Systellommatophora: Eupulmonata: Gastropoda)
}

SOUMEN ROY ( $\nabla$ soumenroyzoology@gmail.com )

City College Kolkata https://orcid.org/0000-0002-3510-0947

\section{Saumita Ghosh}

Banipur Mahila Mahavidyalaya

Narayan Ghorai

West Bengal State University

\section{Samir Saha}

West Bengal State University

\section{Subir Dasgupta}

Maulana Azad College

Korak Kanti Chaki

University of Calcutta

\section{Research Article}

Keywords: Hermaphrodite, Snake shed skin extract, Mollusca, gametogenic ailment, Protandrous

Posted Date: August 5th, 2021

DOI: https://doi.org/10.21203/rs.3.rs-756917/v1

License: (c) (i) This work is licensed under a Creative Commons Attribution 4.0 International License.

Read Full License 


\section{Abstract}

The snake shed skin has long been used in folk as ethnomedicine for the treatment of various therapeutic purposes. The present study investigates the effects of the shed skin aqueous extract (SSAE) of the nonpoisonous snake Ptyas mucosus on the development of the ovotestis of the hermaphrodite slug, Onchidium tigrinum. The ovotestis consists of numerous ovoid-shaped acini, include both spermatogenesis and oogenesis. It is observed that the nonpoisonous SSAE has some significant detrimental effects on the gametogenesis of the slug only on direct contact into the body fluid of the individuals, otherwise, the SSAE has no significant harmful effect on the ovotestis constituents. The most noticeable pathological effects in spermatogenesis are - the arrangement of developing sperm bundles and their typical twisting pattern have deteriorated, the head of the sperm become a small bead-like structure, the pyramidal development of the spermatogenic cells is lower in number in the acini. On the other hand, the oocyte lost its basal integrity with the acinar boundary. The oolemma of the oocytes becomes irregularly shrank. Some small ooplasmic blebbing have commonly been found near the oolemma. The cell membrane of most of the cells in the acini has been damaged and several bare nuclei have frequently been observed in the acinar space. The somatic cells such as Sertoli cells, follicle cells, etc. in the acini appeared as the cellular remnants. It advocates that the SSAE has more detrimental effects on the oogenic cells than that of the spermatogenic cells in the mollusc.

\section{Introduction}

The shed skin of snakes considers as biological waste product and have long been used in folk, Santhal and traditional medicinal system for treatment of various medicinal purposes in India and Chinese (Lev 2003, Costa-Neto 2005, Soewu 2008, Mukherjee et al. 2013). It is described that the poisonous snake (e.g, Naja naja) shed skin aqueous extract (SSAE) composed of some toxic biomolecules, which have some pathological properties on the female reproductive system of Swiss Albino mice such as temporary cessation of the estrous cycle, cellular disorganization in the ovary, uterus and etc. (Mukherjee et al. 2013, 2016). However, no reports are still available about the possible ethnomedicinal effects of the shed skin extract of the non-poisonous snakes in the medicinal treatments of the animal groups.

The Onchidium tigrinum (Stoliczka 1869) is a protandrous, simultaneous, hermaphrodite mollusc of Onchidiidae family (Systellommatophora, Eupulmonata: Gastropoda). During sexual life, 0 . tigrinum acts as the male in the early part of life and perform simultaneous female in later and is corroborated to those of the other pulmonates (Tomiyama 1996; Koene et al. 2007; Norton et al. 2008). Like other pulmonates (Luchtel 1972a, b; Jong-Brink et al. 1981; Norton et al. 2008; Ping 2008), the gonad of the 0 . tigrinum is ovotestis and composed of numerous ovoid-shaped acini (Roy et al. 2018). In pulmonates, both the male and female gametes are developed in each ovotestis acinus with some somatic barrier (Jong-Brink et al. 1976; Eckelbarger and Eckelbarger 1989; Rakshit et al. 2005; Bing et al. 2008; Roy et al. 2016; Roy eta I. 2018; Roy et al. 2019). The body weight of the $O$. tigrinum is directly correlated to the gender choice as well as the predominancy of either the spermatogenesis or oogenesis in their ovotestis acini (Roy et al. 
2018) and these are resembled with the other pulmonates (Tomiyama 1996; Michiels et al. 2003; Koene et al. 2007; Bing 2008; Norton et al. 2008; Hermann et al. 2009; Janssen and Baur 2015; Roy et al. 2016).

The present study aims to investigate the possible effects of the shed skin aqueous extract (SSAE) of the Ptyas mucosus (Linnaeus, 1758) on the developments of various constituents of the ovotestis in the hermaphrodite eupulmonate mollusc, Onchidium tigrinum (Stoliczka 1869).

\section{Materials And Methods}

\subsection{Collection and rearing of sample}

Total 160 Onchidium tigrinum (Stoliczka 1869) (Systellommatophora, Eupulmonata: Gastropoda) of $1 \pm$ $0.5 \mathrm{~g}$ body weight was collected from the bank of river Hooghly (Figs. $1 \mathrm{~A}-\mathrm{B}$ ) at Noorpur $\left(22.1000^{\circ} \mathrm{N}\right.$ and $88.0700^{\circ} \mathrm{E}$ ), South 24-Pargana, West Bengal, during rainy season (June-July month). The body weight of the individuals was taken with a digital weight machine (Mettler Toledo ME204). The specimens were acclimatized for five days in the earthen pot having moist soil of the river basin. The specimens were provided with algal flora and river water was sprayed regularly for maintaining humid ambience.

\subsection{Collection of the snake shed skin of Ptyas mucosus}

The shed skin (Fig. 1D) of the non-poisonous snake, Ptyas mucosus (Linnaeus, 1758) (Colubridae, Squamata, Reptilia) (Fig. 1C) irrespective of the male or female individuals were collected from Purba Medinipur of West Bengal, India through field collection as per permission granted by the Ministry of Forests \& Wild Life, Govt. of West Bengal, India (4250/WL/4R-6/2017). The shed skins were identified by the Zoological Survey of India.

\subsection{Preparation of the snake shed skin aqueous extract (SSAE) and its administration into the slugs}

The shed skin ( $40 \pm 5 \mathrm{mg}$ ) of Ptyas mucosus was powdered with two pinches of sea sand using mortar and pastel. The powder was soaked in $2 \mathrm{ml}$ of river water of the sampling area in a centrifuge tube for overnight at room temperature. The head of the centrifuge tube was sealed with parafilm tape and 2-3 ampoule were prepared. The ampoules were shake well and were centrifuged at $2000 \mathrm{rpm}$ for 30 minutes. The supernatant of the ampoule was drawn by a syringe and used as a snake shed skin aqueous extract (SSAE) in the study.

\subsection{Experimental design}

All the collected $O$. tigrinum were divided into four groups. Each group $(\mathrm{N}=40)$ was kept individually in four medium size earthen pots marked as Pot-A, Pot-B, Pot-C and Pot-D (Fig. 2). The individuals in Pot-A, Pot-B, Pot-C and Pot-D were designed as control (Cont.) slugs, only mantle pricked (MP) slugs, only SSAE treated (SSAE) slugs without mantle pricking and SSAE treatment on mantle pricked (MP + SSAE) slugs respectively (Fig. 2). The mantle of the slugs in Pot-B and Pot-D was pricked by the sharp tip of a fine 
needle. In Pot-C, the SSAE of one ampoule was sprayed once in a day on the mantle (dorsal surface) of the slugs. In Pot-D, the individuals were mantle pricked first and then one ampoule SSAE was immediately sprayed on those individuals. The ovotestes from these four groups were collected and processed for simple histological analysis (Fig. 2).

\section{GSI $(\%)=\underline{\text { Weight of the ovotestis } \times 100}$ \\ Total body weight of the individual}

The weight of the ovotestis was compared with the overall body weight of the individuals and a gonadosomatic index (GSI) was calculated for four groups (Bing et al. 2008).

GSI $(\%)=$ Weight of the ovotestis $\times 100$

Total body weight of the individual

\subsection{Histopathological analysis}

According to the experimental design (Fig. 2), on the day 15 the ovotestes were dissected out from some living slugs $(\mathrm{N}=15)$ from each earthen pot (i.e., Pot-A, Pot-B, Pot-C and Pot-D) and immediately preserved in the aqueous Bouin's solution in individual microtube at room temperature. After 2-3 hours the ovotestis was cut into some small pieces $\left(3-4 \mathrm{~mm}^{3}\right)$ and kept in the microtube with fresh fixative for 1416 hours at room temperature. The fixed samples were washed with tap water and dehydrated with ethanol, embedded in paraffin $\left(58-60^{\circ} \mathrm{C}\right)$ and serially sectioned $(5 \mu \mathrm{m})$. The sections were stained with the haematoxylin and eosin and were observed under a light microscope.

\subsection{Morphometry and statistical analysis}

The measurement (mean value \pm SD) of the various acinar constituents such as the size of spermatocytes, spermatids, sperms, oogonia, oocytes, Sertoli cells, follicle cells, width of the acinar boundary, follicular layer, follicular cleft, and etc. were taken from the four groups using image-processing software "ImageJ 1.51t" (Wayne Rasband, NIH, USA).

A normality test was applied to check the distributions of the studied acinar features among the four experimental groups of the slug. The test met the assumption of parametric analysis and one way ANOVA followed by Tukey's test was performed using XLSTAT statistical program to determine the statistical significance $(P<0.05)$ on the developmental variations of the different acinar components among these experimental groups.

\section{Results}

\subsection{General characteristics of the acini in the ovotestis}


The ovotestis of Onchidium tigrinum was the single globular mass (28.34 $\pm 4.93 \mathrm{mg}$ in weight), which consists of numerous sac-like acini, which were well decorated with several structural characteristics such as developing gametogenic cells, somatic cells, connective tissue and etc. (Figs. 3A-E, 4A-B). The acinar boundary $(0.18 \pm 0.002 \mu \mathrm{m}$ in thickness) was well-developed with some characteristics interacinar space (1.26 $\pm 0.22 \mu \mathrm{m}$ in width) (Figs. 3A, 3C-D, 4B) and interacinar junction ( $0.16 \pm 0.04 \mu \mathrm{m}$ in width) (Figs. 3B-C). The interacinar space was included small, ovoid interacinar cells, connective tissue and blood vessels. Some small nucleated cells were observed in the acinar boundary (Figs. 3B-C, 4B). The entire acinus space was divided into a cortex region and a lumen (or medulla) termed as the acinar cortex and acinar lumen. Each acinus ( $8.32 \pm 0.32 \times 8.15 \pm 0.62 \mu \mathrm{m}$ in size) composed of numerous developing spermatogenic cells and a few numbers of developing oogenic cells with some corresponding somatic cells (Figs. 3A-D, 4A-B).

\subsubsection{Spermatogenic cells}

Several sections revealed that numerous spermatogenic cells with various developing stages; i.e., spermatogonia, spermatocytes, spermatids and sperms were distributed throughout the acinar space (Figs. 3A-D, 4A-B).

The spermatogonia ( $0.34 \pm 0.028 \mu \mathrm{m}$ in diameter) were mostly circular, smaller in size with centrally placed deeply stained nucleus and were mainly found in the acinar cortex (Figs. 3A-B, 4A-B Sketch). The spermatocytes ( $1.16 \pm 0.173 \mu \mathrm{m}$ in diameter) were oval or pear-shaped, larger in size than the spermatogonia (Figs. 3A-B, 4A-B). The spermatids were developed from the large spherical cell $(0.33 \pm$ $0.06 \mu \mathrm{m}$ in diameter) to the elongated cell $(1.47 \pm 0.22 \mu \mathrm{m}$ in length). The budding tail parts of the developing spermatids were showed in the cortical region in several acini (Fig. 4A). The residual part of the excess cell cytoplasm in the developing elongated spermatids were accumulated very near to their tail (Figs. 3E, 4B). The sperms were mainly found as the sperm bundles measured approximately $6.30 \mu \mathrm{m}$ in length and $0.85 \mu \mathrm{m}$ in width (Figs. 3A, 4A-B). It was observed that the sperms in almost all the sperm bundles maintained a typical twisting fashion with each other along with the tail length (Figs. 3A, 4A-B). The head $(0.19 \pm 0.01 \mu \mathrm{m}$ in length) of sperms in the sperm bundle were inserted into a part of the Sertoli cell (Figs. 3A, 4A-B).

\subsubsection{Oogenic cells}

The developing oogenic cells were only restricted in a few portions of the acinar cortex (Figs. 3A, 3C, 3D, $4 A-B)$. One part of the developing oogenic cells were very intimately attached to the inner wall of the acinar boundary, whereas their luminal face was covered by a developing follicular layer of the follicle cells (Figs. 3A, 3C, 4B). Three to four developing oogenic cells including the oogonium and oocytes were found in most of the ovotestis acini (Figs. 3A, 3C, 3D, 4A-B).

The oogonium was commonly observed as an elongated cell measured $2.75 \pm 0.85 \mu \mathrm{m}$ in length and $1.03 \pm 0.23 \mu \mathrm{m}$ in width (Figs. 3A, 4B). The luminal portion of the oogonium was partially covered with a poorly-developed follicular layer (Figs. 3A, 4B). The oocytes were oval to circular in shape measured 4.05 
$\pm 0.41 \mu \mathrm{m}$ in diameter (Figs. 3A, 3C, 3D, 4A-B). The oocyte was surrounded by a well-developed follicular layer $(0.20 \pm 0.02 \mu \mathrm{m}$ in thickness). A follicular cleft $(0.20 \pm 0.12 \mu \mathrm{m}$ in width) was developed between the oolemma and the follicular layer at the apical and lateral surfaces of the oocytes (Figs. 3A, 3D, 4B). The ooplasm was characterized by a mosaic matrix of some light and opaque materials (Figs. 3A, 3C, 3D, 4B). The nucleus of the oocytes was prominent measured $2.05 \pm 0.14 \mu \mathrm{m}$ in diameter with distinct nucleolus (Figs. 3A, 3D).

\subsubsection{Somatic cells}

In the ovotestis, there were four major somatic cells such as the Sertoli cells and follicle cells in the acini, whereas the periacinar cells and interacinar cells out site the acinar boundary (Figs. 3A-C, 4A-B).

The Sertoli cells were very irregular in shape and size (Figs. 3A-C, 4A-B). Sertoli cells were spermatogenesis promoting cells for which most of the developing spermatogenic cells were developed in the vicinity of the Sertoli cells (Figs. 3A-D, 4A-B). In the acinar cortex, one part of the Sertoli cells was very tightly attached to the inner wall of the acinar boundary and rest of the luminal cell surface was covered with a pyramidal aggregation of numerous developing spermatogenic cells, described as spermatogenic cell pyramid (Figs. 3A-B, 4B sketch).

The follicle cells were thin, short cells measured $0.29 \pm 0.08 \mu \mathrm{m}$ in length and $0.18 \pm 0.05 \mu \mathrm{m}$ in width. Follicle cells were few in number, arranged in a layer around the developing oocytes described as follicular layer (Figs. 3A, 3D, 4B). Several sections revealed that an intermingled barrier was sometimes formed by an association of the follicle cell and a part of Sertoli cell on the luminal surface of some developing oogenic cells (Fig. 4A) and avoids direct contact of the developing spermatogenic cells to the developing oogenic cells (Figs. 3A, 4A-B). The thickness of the intermingled cell barrier was approximately two times greater in thickness than that of the typical follicular layer measured $0.20 \pm 0.02$ $\mu \mathrm{m}$ in width (Figs. 3A, 3D, 4A-B).

The periacinar cell was a slightly elongated $(0.22 \pm 0.05 \mu \mathrm{m}$ in length), thin cells $(0.07 \pm 0.02 \mu \mathrm{m}$ in width) and was very tightly adhered to the outer wall of the acinar boundary with some muscle fibers (Figs. 3A, 3C, 4A-B).

The interacinar cells $(0.08 \pm 0.025$ in diameter) were mostly circular or oval cells with a deeply stained, prominent nucleus (Figs. 3C, 4B). The interacinar cell was irregularly distributed as either singly or a bunch of cells in the interacinar space $(1.26 \pm 0.22 \mu \mathrm{m}$ in width) and approximately half in length than that of the periacinar cells $(0.22 \pm 0.05 \mu \mathrm{m})$ (Figs. 3A, 3C, 4B).

\subsection{Variations of the acinar components after different treatments}

According to work design (Fig. 2), there were three different treatments such as the mantle pricked specimens (MP slugs, in Pot-B), only snake shed skin aqueous extract (SSAE) treated specimens (SSAE slugs, in Pot-C) and the mantle pricked individuals with SSAE treated specimens (MP + SSAE slugs, in 
Pot-D). The Relative characteristics (Table 1) and the morphometry (Table 2) of various ovotestis constituents of the control and three treated groups were tabulated here. The normality test of the various ovotestis constituents was suggested that all the variables were normally distributed in the four groups of the slug (Table 3). 
Table 1

Relative characteristics of the acinar constituents in the four groups of Onchidium tigrinum. Cont., control individuals; MP, mantle pricked individuals; SSAE, only snake shed skin aqueous extract treated individuals; MP + SSAE, snake shed skin aqueous extract treatment on mantle pricked individuals.

\begin{tabular}{|c|c|c|c|c|}
\hline $\begin{array}{l}\text { Acinar } \\
\text { features }\end{array}$ & $\begin{array}{l}\text { Cont. } \\
(\mathrm{N}=40)\end{array}$ & $\begin{array}{l}\text { MP } \\
(N=40)\end{array}$ & $\begin{array}{l}\text { SSAE } \\
(N=40)\end{array}$ & $\begin{array}{l}M P+S S A E \\
(N=40)\end{array}$ \\
\hline $\begin{array}{l}\text { Acinar } \\
\text { boundary }\end{array}$ & $\begin{array}{l}\text { Thick, smooth, double } \\
\text { membrane bound } \\
\text { structure }\end{array}$ & $\begin{array}{l}\text { Thick, } \\
\text { smooth, } \\
\text { double } \\
\text { membrane } \\
\text { bound } \\
\text { structure }\end{array}$ & $\begin{array}{l}\text { Thick, smooth, } \\
\text { double } \\
\text { membrane } \\
\text { bound } \\
\text { structure }\end{array}$ & $\begin{array}{l}\text { Relatively thin, with } \\
\text { numerous granular } \\
\text { materials. }\end{array}$ \\
\hline $\begin{array}{l}\text { Spermato- } \\
\text { genic cells }\end{array}$ & $\begin{array}{l}\text { Commonly found, } \\
\text { distributed throughout } \\
\text { the acinar space }\end{array}$ & $\begin{array}{l}\text { No significant } \\
\text { variation than } \\
\text { control }\end{array}$ & $\begin{array}{l}\text { No significant } \\
\text { variation than } \\
\text { control }\end{array}$ & $\begin{array}{l}\text { Very ill-defined structure, } \\
\text { bare nucleus of various } \\
\text { developing sages was } \\
\text { found throughout the } \\
\text { acinar space }\end{array}$ \\
\hline $\begin{array}{l}\text { Sperm } \\
\text { bundles }\end{array}$ & $\begin{array}{l}\text { Abundant, well } \\
\text { developed with } \\
\text { typically spiral tail. }\end{array}$ & $\begin{array}{l}\text { No } \\
\text { characteristic } \\
\text { variation than } \\
\text { control }\end{array}$ & $\begin{array}{l}\text { No } \\
\text { characteristics } \\
\text { variation than } \\
\text { control }\end{array}$ & $\begin{array}{l}\text { Most of the sperm } \\
\text { bundles were appeared } \\
\text { as a hazy woolly } \\
\text { structure. Numerous } \\
\text { sperms were lonely and } \\
\text { randomly distributed far } \\
\text { away from the vicinity of } \\
\text { the Sertoli cell. }\end{array}$ \\
\hline $\begin{array}{l}\text { Sperm } \\
\text { heads }\end{array}$ & $\begin{array}{l}\text { Pointed, inserted into a } \\
\text { part of Sertoli cell }\end{array}$ & $\begin{array}{l}\text { No } \\
\text { distinguishing } \\
\text { variation than } \\
\text { control }\end{array}$ & $\begin{array}{l}\text { No } \\
\text { distinguishing } \\
\text { variation than } \\
\text { control }\end{array}$ & $\begin{array}{l}\text { Blunt, most of the } \\
\text { sperms were distantly } \\
\text { placed from the Sertoli } \\
\text { cells }\end{array}$ \\
\hline $\begin{array}{l}\text { Sertoli } \\
\text { cell }\end{array}$ & $\begin{array}{l}\text { Abundant, well } \\
\text { developed with } \\
\text { prominent nucleus }\end{array}$ & $\begin{array}{l}\text { No significant } \\
\text { variation than } \\
\text { control }\end{array}$ & $\begin{array}{l}\text { No significant } \\
\text { variation than } \\
\text { control }\end{array}$ & $\begin{array}{l}\text { Mainly residual portion } \\
\text { of the Sertoli cells were } \\
\text { found. Bare nucleus of } \\
\text { the Sertoli cells was also } \\
\text { observed. }\end{array}$ \\
\hline $\begin{array}{l}\text { Interacinar } \\
\text { cell }\end{array}$ & $\begin{array}{l}\text { Ovoid shaped with } \\
\text { distinct nucleus, } \\
\text { mostly found as a } \\
\text { small bunch of the } \\
\text { cells }\end{array}$ & $\begin{array}{l}\text { No } \\
\text { distinguishing } \\
\text { variation than } \\
\text { control }\end{array}$ & $\begin{array}{l}\text { No } \\
\text { distinguishing } \\
\text { variation than } \\
\text { control }\end{array}$ & $\begin{array}{l}\text { Rarely found, } \\
\text { comparatively smaller in } \\
\text { size, circular, mainly } \\
\text { distributed discretely in } \\
\text { the interacinar space. }\end{array}$ \\
\hline $\begin{array}{l}\text { Periacinar } \\
\text { cell }\end{array}$ & $\begin{array}{l}\text { Thin, elongated cell, } \\
\text { frequently found, } \\
\text { tightly attached to the } \\
\text { outer wall of the acinar } \\
\text { boundary }\end{array}$ & $\begin{array}{l}\text { No } \\
\text { characteristic } \\
\text { variation than } \\
\text { control }\end{array}$ & $\begin{array}{l}\text { No } \\
\text { characteristics } \\
\text { variation than } \\
\text { control }\end{array}$ & Indistinct, rarely found \\
\hline
\end{tabular}




\begin{tabular}{|lllll|}
\hline $\begin{array}{l}\text { Acinar } \\
\text { features }\end{array}$ & $\begin{array}{l}\text { Cont. } \\
(\mathbf{N}=\mathbf{4 0})\end{array}$ & $\begin{array}{l}\text { MP } \\
\mathbf{( N = 4 0 )}\end{array}$ & $\begin{array}{l}\text { SSAE } \\
\mathbf{( N = 4 0 )}\end{array}$ & $\begin{array}{l}\text { MP+SSAE } \\
\mathbf{( N = 4 0 )}\end{array}$ \\
\hline Oogenic & $\begin{array}{l}\text { Oval or circular } \\
\text { shaped, surrounded by } \\
\text { well-developed } \\
\text { follicular layer. Located } \\
\text { in only the cortex } \\
\text { region of the acini }\end{array}$ & $\begin{array}{l}\text { Similar to the } \\
\text { control }\end{array}$ & $\begin{array}{l}\text { Similar to the } \\
\text { control }\end{array}$ & $\begin{array}{l}\text { The oolemma around } \\
\text { the developing oogenic } \\
\text { cells was drastically } \\
\text { damaged, bare nucleus } \\
\text { of the oocytes were } \\
\text { frequently found and } \\
\text { distributed throughout } \\
\text { the acinar space. }\end{array}$ \\
$\begin{array}{llll}\text { Ooplasmic } \\
\text { blebbing }\end{array}$ & $\begin{array}{l}\text { Not found in any } \\
\text { section }\end{array}$ & $\begin{array}{l}\text { Not found in } \\
\text { any section }\end{array}$ & $\begin{array}{l}\text { Not found in } \\
\text { any section }\end{array}$ & $\begin{array}{l}\text { Most frequently found in } \\
\text { almost all sections }\end{array}$ \\
$\begin{array}{l}\text { Follicular } \\
\text { layer }\end{array}$ & $\begin{array}{l}\text { Thick, well-developed } \\
\text { with a distinct } \\
\text { follicular cleft around } \\
\text { the developing oocytes }\end{array}$ & $\begin{array}{l}\text { No } \\
\text { characteristic } \\
\text { variation than } \\
\text { control }\end{array}$ & $\begin{array}{l}\text { No } \\
\text { characteristics } \\
\text { variation than } \\
\text { control }\end{array}$ & $\begin{array}{l}\text { Very ill-defined, } \\
\text { drastically damaged } \\
\text { around the developing } \\
\text { oocytes }\end{array}$ \\
\hline
\end{tabular}


Table 2

Morphometric comparisons (mean value \pm SD) of the acinar constituents between control and three experimental groups of Onchidium tigrinum. Cont., control individuals; MP, mantle pricked individuals; SSAE, only snake shed skin aqueous extract treated individuals; MP + SSAE, snake shed skin aqueous extract treatment on mantle pricked individuals.

\begin{tabular}{|lllll|}
\hline Acinar features & Cont. & MP & SSAE & MP+SSAE \\
\hline Width of acinar boundary & $\mathbf{( N = 4 0 )}$ & $\mathbf{( N = 4 0 )}$ & $\mathbf{( N = 4 0 )}$ & $\mathbf{( N = 4 0 )}$ \\
\hline Spermatogonium diameter & $0.18 \pm 0.002$ & $0.2 \pm 0.031$ & $0.16 \pm 0.024$ & $0.016 \pm 0.002$ \\
\hline Spermatocyte diameter & $0.34 \pm 0.028$ & $0.25 \pm 0.007$ & $0.15 \pm 0.004$ & $0.15 \pm 0.03$ \\
\hline Spermatocyte nucleus diameter & $1.16 \pm 0.173$ & $0.28 \pm 0.033$ & $0.29 \pm 0.019$ & $0.31 \pm 0.053$ \\
\hline Spermatid diameter & $0.59 \pm 0.107$ & $0.19 \pm 0.041$ & $0.18 \pm 0.025$ & $0.25 \pm 0.031$ \\
\hline Sperm length & $0.33 \pm 0.058$ & $0.20 \pm 0.012$ & $0.33 \pm 0.133$ & $0.03 \pm 0.006$ \\
\hline Sperm bundle width & $6.30 \pm 1.039$ & $4.33 \pm 0.157$ & $2.28 \pm 0.28$ & $0.35 \pm 0.013$ \\
\hline Sperm head length & $0.85 \pm 0.070$ & $0.63 \pm 0.040$ & $0.77 \pm 0.22$ & $0.35 \pm 0.112$ \\
\hline Sertoli cell diameter & $0.19 \pm 0.010$ & $0.20 \pm 0.050$ & $0.13 \pm 0.002$ & $0.01 \pm 0.002$ \\
\hline Sertoli cell nucleus & $3.17 \pm 0.528$ & $1.04 \pm 0.367$ & $2.02 \pm 0.189$ & $0.12 \pm 0.021$ \\
\hline Height of spermatogenic cell pyramid & $1.45 \pm 0.095$ & $1.66 \pm 0.476$ & $1.61 \pm 0.066$ & $0.45 \pm 0.118$ \\
\hline Width of spermatogenic Cell pyramid & $1.40 \pm 0.296$ & $0.85 \pm 0.155$ & $1.52 \pm 0.370$ & $0.40 \pm 0.092$ \\
\hline Oogonium length & $2.75 \pm 0.854$ & $2.21 \pm 0.496$ & $2.58 \pm 0.46$ & $0.76 \pm 0.124$ \\
\hline Oogonium width & $1.01 \pm 0.203$ & $0.41 \pm 0.021$ & $0.73 \pm 0.165$ & $0.06 \pm 0.005$ \\
\hline Oocyte diameter & $4.05 \pm 0.414$ & $2.97 \pm 0.675$ & $1.86 \pm 0.644$ & $0.98 \pm 0.062$ \\
\hline Oocyte nucleus diameter & $2.05 \pm 0.137$ & $1.07 \pm 0.203$ & $1.49 \pm 0.129$ & $0.37 \pm 0.031$ \\
\hline Follicular layer thickness & $0.20 \pm 0.019$ & $0.10 \pm 0.016$ & $0.09 \pm 0.015$ & $* *$ \\
\hline Follicular cleft width & $0.20 \pm 0.118$ & $0.20 \pm 0.026$ & $0.13 \pm 0.055$ & $* *$ \\
\hline Interacinar cell diameter & $0.08 \pm 0.025$ & $0.08 \pm 0.022$ & $0.08 \pm 0.025$ & $0.02 \pm 0.007$ \\
\hline Periacinar cell length & $0.22 \pm 0.053$ & $0.22 \pm 0.053$ & $0.22 \pm 0.057$ & $0.02 \pm 0.002$ \\
\hline ** absent in the group. & & & & $0.38 \pm 0.006$ \\
\hline
\end{tabular}


Table 3

The calculated P-value of the various constituents of the ovotestis acini using the normality test (Shapiro-Wilk test). Individual P-value was greater than the alpha value (0.05). All the variables were normally distributed in the four groups of Onchidium tigrinum. Cont., control individuals; MP, mantle pricked individuals; SSAE, only snake shed skin aqueous extract treated individuals; $M P+S S A E$, snake shed skin aqueous extract treatment on mantle pricked individuals.

\begin{tabular}{|lllll|}
\hline Acinar characteristics & Cont. & MP & SSAE & MP + SSAE \\
& $(\mathbf{N}=\mathbf{4 0})$ & $\mathbf{( N = 4 0 )}$ & $\mathbf{( N = 4 0 )}$ & $(\mathbf{N}=\mathbf{4 0})$ \\
\hline Width of acinar boundary (abW) & 0.17 & 0.17 & 0.30 & 0.83 \\
\hline Spermatogonium diameter (sg) & 0.09 & 0.68 & 0.20 & 0.46 \\
\hline Spermatocyte diameter (sc) & 0.21 & 0.17 & 0.34 & 0.50 \\
\hline Spermatocyte nucleus diameter (scN) & 0.30 & 0.09 & 0.29 & 0.84 \\
\hline Spermatid diameter (sd) & 0.32 & 0.07 & 0.10 & 0.84 \\
\hline Sperm bundle width (sbW) & 0.16 & 0.60 & 0.19 & 0.31 \\
\hline Sperm head length (spH) & 0.33 & 0.21 & 0.48 & 0.25 \\
\hline Sertoli cell diameter (S) & 0.12 & 0.12 & 0.15 & 0.35 \\
\hline Sertoli cell nucleus (SN) & 0.18 & 0.12 & 0.23 & 0.38 \\
\hline Height of spermatogenic cell pyramid (sgpH) & 0.05 & 0.27 & 0.26 & 0.25 \\
\hline Width of spermatogenic Cell pyramid (sgpW) & 0.24 & 0.13 & 0.14 & 0.47 \\
\hline Oogonium length (ogL) & 0.18 & 0.61 & 0.36 & 0.23 \\
\hline Oogonium width (ogW) & 0.53 & 0.24 & 0.15 & 0.31 \\
\hline Oocyte diameter (oc) & 0.18 & 0.16 & 0.14 & 0.65 \\
\hline Oocyte nucleus diameter (ocN) & 0.43 & 0.17 & 0.23 & 0.56 \\
\hline Interacinar cell diameter (ic) & 0.42 & 0.82 & 0.55 & 0.20 \\
\hline Periacinar cell length (pc) & 0.44 & 0.07 & 0.31 & 0.33 \\
\hline
\end{tabular}

\subsubsection{The acinar components in the ovotestis of the mantle pricked slugs (MP slugs) and only SSAE treated slugs (SSAE slugs)}

It was observed that the weight of the ovotestes and the gonado somatic index (GSI) in the individuals of the MP (28.14 $\pm 3.99 \mathrm{mg}$ in weight) and SSAE (28.20 $\pm 2.98 \mathrm{mg}$ in weight) groups have no significant differences to those of the control (28.34 $\pm 4.93 \mathrm{mg}$ in weight) individuals (Fig. 5). Moreover, the structural characteristics of the various acinar components in the ovotestis of the MP slugs (Fig. 6A) and SSAE slugs (Fig. 6B) were almost same with those of the control specimen (Figs. 3A-D, 4A-B) (Tables 1). 


\subsubsection{The acinar components after spraying of the SSAE on the mantle pricked slugs (MP + SSAE slugs)}

In the present study, it was noted that the combinations of the mantle pricking and spraying of the SSAE have a great detrimental effect on the development of the gametogenic cells (Figs. 7A-B, 8A-C, 9, 10A-F, 11A-F, 12A-C, 13A-D and Tables 2 and 4). The weight of the ovotestis (16.5 $\pm 9.37 \mathrm{mg}$ in weight) of the 'MP + SASAE' slugs was desperately decreased than that of the control slug $(28.34 \pm 4.93 \mathrm{mg}$ in weight) and other treated slugs (Fig. 5). Most significant differences of the ovotestis characteristics between the control slugs (Figs. 3A-D, 4A-B) and the 'MP + SSAE' slugs (Figs. 7A-B, 8A-C, 9, 10A-F, 11A-F, 12A-C, 13A-D) were tabulated in the Table 4. A characteristic difference in the GSI indices was observed between the individuals of the control and 'MP + SSAE' groups (Fig. 6)

Table 4

Some major comparative characteristics of acinar constituents in the ovotestis between control (Cont.) and snake shed skin aqueous extract treatment on mantle pricked (MP + SSAE) individuals.

\begin{tabular}{|c|c|c|c|}
\hline SI. No. & Acinar Features & Cont.* & $M P+S S A E^{*}$ \\
\hline 1. & Granulation in the acinar boundary & - & +++ \\
\hline \multirow[t]{2}{*}{2.} & Intimate association between acinar boundary & +++ & - \\
\hline & with different acinar components & & \\
\hline 3. & Bare nucleus of developing spermatogenic cells & - & +++ \\
\hline 4. & Sperm bundles & +++ & + \\
\hline 5. & Spiral pattern of sperm bundle & +++ & + \\
\hline 6. & Individual sperms & + & +++ \\
\hline 7. & Sertoli cells & +++ & + \\
\hline 8. & Bare nucleus of developing oogenic cells & - & +++ \\
\hline 9. & Ooplasmic blebbing & - & +++ \\
\hline 10. & Follicle cell & ++ & - \\
\hline 11. & Follicular layer & +++ & - \\
\hline 12. & Follicular cleft & +++ & - \\
\hline
\end{tabular}

The acinar size of the 'MP + SSAE' slugs (Fig. 7A) was slightly larger in length $(9.04 \pm 0.34 \mu \mathrm{m})$ and smaller in width $(4.71 \pm 0.37 \mu \mathrm{m})$ than those of the control slugs $(8.32 \pm 0.32 \times 8.15 \pm 0.62 \mu \mathrm{m}$ in size $)$ (Fig. 3A). The acinar boundary was become granulated by darkly stained small granules (Figs. 7B, 8A, 8C, 
9). The nucleated cells in the acinar boundary were very indistinct or rarely observed (Figs. Figures 7A-B, 8A-C, 9). The interacinar space was mostly devoid from the interacinar cells (Figs. 7A-B, 8C, 9).

\subsubsection{Spermatogenic cells}

Most of the developing spermatogenic cells in the acini were found as distorted structures (Figs. 7A-B, 8A$C, 9)$. The developing spermatogenic cells were lost their typical shape, size and their intimate associations with the Sertoli cells (Figs. 7A-B, 8A-C, 9). The morphometry of various spermatogenic features was decreased than those in the control specimens (Figs. 10B-F, 11A-C, Table 2). Residual parts of the sperm bundles in the most acini were irregularly distributed and were lost their typical spiral fashion toward the tail (Figs. 7A-B, 8A-C, 9). The sperm heads were characterized by a small, bead-like structure (Figs. 7A-B, 8A, 8C, 9). Several individual sperms instead of sperm bundles were frequently found in the acini. The height and width of cell pyramid of the spermatogenic cells were drastically decreased than those of the control slugs (Figs. 11B, 11C). Many bare nuclei of the developing spermatogenic cells were frequently observed without cell cytoplasm in most sections (Figs. 7A, 8A-C, 9).

\subsubsection{Oogenic cells}

The developing oogenic cells were lost their tight, intimate association with the acinar boundary (Figs. 7AB, 8A-C, 9). The morphometry of the oogonia (Figs. 7B, 11F, 12A) and oocytes (Figs. 7A-B, 8A-C, 9, 12B-C) in the acini was significantly varied from those in the acini of the control individuals as well as in the MP and SSAE treated slugs. The typical follicle cells and follicular layer around the developing oocytes were drastically damaged (Figs. 8A, 8C, 9). As a result, the oocytes were dislocated from the acinar cortex toward the acinar lumen (Figs. 7A, 8C, 9). The smooth oolemma of the developing oocytes were distorted and some distinct ooplasmic blebs were separated from the oocyte (Figs. 8B-C, 9). The nuclear membrane of the developing oocytes become thicker than that of the control slugs (Fig. 9). Several serial sections revealed that many bare nuclei of the developing oogenic cells were frequently observed in the acini (Figs. 7A, 8A-C, 9).

\subsubsection{Somatic cells}

The somatic cells such as the Sertoli cells, follicle cells, periacinar cells and interacinar cells in the 'MP + SSAE' treated slugs were morphologically and morphometrically declined than those of the control slugs (Figs. 7A-B, 8A-C, 9, 11D-E, 13A-D). Several sections revealed that mainly remnants of the Sertoli cells were found. The bare nucleus of the Sertoli cells was also found in many acini (Fig. 7B). The follicular layer and follicular cleft were absent around the developing oocytes in the most of the acini (Figs. 7A-B, $8 \mathrm{~A}-\mathrm{C}, 9,13 \mathrm{~A}-\mathrm{B}$ and Tables 1,4). The cell size and the population of the interacinar cells and periacinar cells were significantly decreased in the ovotestis of 'MP + SSAE' treated slugs (Figs. 7A-B, 8A, 8C, 9, 13CD).

The developmental relationship of the various ovotestis features in both the MP and SSAE slugs was more or less same with those of the control slugs (Figs. 3A-D, 4A-B, 5, 6A-B, 10A-F, 11A-F, 12A-C, 13A-D and Tables 1-2). The GSI index clearly shown that there was a significant variation between the 
individuals (MP + SSAE group) with direct contact of the SSAE and other groups (Fig. 5). The study was advocated that the SSAE of the $P$. mucosus was performed as a zootherapeutic resources and its ingredients showing some therapeutic effects in the reproductive tissue of the slugs on its direct contact to the individual body fluid.

\section{Discussion}

The Ptyas mucosus is a non-poisonous snake and preying on rodents, toads, lizards and other snakes with a great importance in the food chain of a terrestrial ecosystem. It has beneficial effects to treat the rheumatoid arthritis and various nameless pains (Zhou et al. 2016). The present study describes the possible effects of the shed skin aqueous extract (SSAE) of the Ptyas mucosus on the development of the ovotestis constituents in the hermaphrodite slug, Onchidium tigrinum for the first time. The morphoanatomical characteristics of the ovotestis of 0 . tigrinum are mostly similar to those of the other slugs (Quatrini and Lanza 1965; Bing et al. 2008; Roy et al. 2019). In the present study, it is observed that the morphostructural characteristics of the ovotestis acini in the individuals of the control group are almost identical with those of the only mantle pricked (MP) slugs and only SSAE treated slugs, while those are drastically deviated in the ovotestis of the SSAE treated mantle pricked (MP + SSAE) slugs. It is presumed that like reproductive tissue, the ingredients of the shed skin of the $P$. mucosus may have some therapeutic effects in other tissues of various system (e.g., nervous system, olfactory system, etc.) on its direct contact to the animal body fluid.

The gonado somatic index in the 0 . tigrinum clearly shown that the normal development of the ovotestis is drastically lower in the 'MP + SSAE' slugs and it may be due to the cessation of the gonadal developmental by the ingredients of the SSAE of $P$. mucosus and this kind of effects also found in the reproductive system of the Swiss Albino mice on the administration of the shed skin extract of poisonous snake (e.g., Naja naja) (Mukherjee et al. 2013, 2016).

It is observed that the cytoskeleton of developing oogenic cells are more damaged than that of the spermatogenic cells in the acini of 'MP + SSAE' treated slugs. It is presumed that a dose control subcutaneous administration of the SSAE of the nonpoisonous snake may arrest or inhibit the oogenesis in a hermaphroditic gonad and acts as a zootherapeutic resource to conversion of the hermaphroditic gonad to the male-specific gonad in the animal groups but this requires further investigations.

According to the molecular evolution the non-poisonous snake family Colubridae (e.g., Ptyas mucosus, Elaphe bimaculate, etc.) and poisonous snake family Elapids (e.g., Naja naja, etc.) share a common ancestor group such as Caenophidia (Knight and Mindell 1994; Geng et al. 2011; Zaher et al. 2012; ReyesVelasco et al. 2014; Zaher et al. 2019). It is assumed that, the residing factor or bioactive molecules in the shed skin of both the non-poisonous Ptyas mucosus and some poisonous snakes (e.g., Naja naja, etc.) (Mukherjee et al. 2013, 2016) may be similar to some extend and therefore they have some kind of medicinal effects on the reproductive tissues. Additionally, the Ptyas mucosus is phylogenetically closely related to a monophyletic group of Elaphe genus (e.g., Elaphe bimaculate, Elaphe anomala, etc.). It is 
presumed that the shed skin of all these nonpoisonous snakes may act as zootherapeutic resource and use in some treatments on their direct contact to the individual body fluid.

The acinar boundary become characteristically granulated in the ovotestis of 'MP + SSAE' slugs and may be due to accumulation of the cellular products of the nucleated cells in the acinar boundary. The ornamentation of the developing male and female gametes in the acini is greatly hampered and bare nuclei of the developing gametes are frequently found in several ovotestis sections in the individuals of the 'MP + SSAE' group. Several sections revealed that the accumulation of the membrane bound cell cytoplasm is observed near the tail region of the developing spermatids which may be released as residual cell cytoplasm through the tail tips of the sperm bundle (Jong-Brink et al. 1977). It is found that the cell membrane and the cell cytoplasm are more affected than other cellular components and are drastically depleted around the developing oocytes, Sertoli cells, spermatogenic cells. Some cytoplasmic blebbing are found near the oolemma of the developing oocytes and it may be due to the effects of necrosis of the gametes.

The Ptyas sp including P. mucosus is commonly found in the forest floors, wetlands, rice paddies, farmland, and etc. areas, where they prey upon small reptiles, amphibians, birds, and mammals (Manthey and Grossmann, 1997). It is reported that the raw as well as tanned skin of Ptyas sp is imported and exported in various countries (e.g., China, Indonesia, etc.) with a good commercial value (Lee et al. 2004, Saputra 2008), whereas the shed skin of the Ptyas is also frequently found in their respective habitats as an inattentive waste material. The results of the present study advocate that the direct contact of the of shed skin of the $P$. mucosus to the body fluid has some detrimental effects on the gametogenesis and may use as a zootherapeutic materials in the animal development. This study may be helpful in the conservation of the Ptyas species and other nonpoisonous snakes for using the prospective values of the shed skin extract in the pharmacology (Lev 2003; Costa-Neto 2005; Zhou et al. 2016).

\section{Conclusion}

The present study described that the ovotestis of the Onchidium tigrinum consist of numerous, small, ovoid-shaped acini. The spermatogenesis and oogenesis are simultaneously developed in the ovotestis acini. Only on direct contact of the shed skin aqueous extract of the non-poisonous Ptyas mucosus to the body fluid of the slug has highly detrimental effects on the developing gametes. However, the structural conformity of the developing oogenic cells is more damaged than that of the developing spermatogenic cells. The study advocates that the SSAE of the $P$. mucosus is performed as a zootherapeutic resources and its constituents showing some therapeutic effects in the reproductive tissue of the slugs on its direct contact to the individual body fluid.

\section{Declarations}

\section{Acknowledgement}


The authors express thanks to the head and all other faculty members of the Department of Zoology, City College, Kolkata, West Bengal, India for their necessary help in the light microscopic study. We are grateful to the Ministry of Forests \& Wild Life, Govt. of West Bengal, India for their permission to use some shed skin of the snake. The authors are thankful to Dr. A. Mukherjee and all other faculty members of Mollusca Section, Zoological Survey of India, India, for the identification of the specimen and instrumental support for light microscope photographic services.

\section{Funding}

The present work is not financially supported by any third party.

\section{Conflicts of interest}

There are no conflicts of interest in the study.

\section{Author's contribution}

S.R.: Collect of samples, work design, preparation of Shed Skin Aqueous Extract (SSAE) of Ptyas mucosus, dissection of the slug, schematic drawing of the ovotestis acinus, tissue processing for histology, microscopy, photography, statistical analysis, graphical representations, and morphological and morphometry data collection, preparation of text, tables, figures with their illustrations, arrangement of tables and figures, official formalities to get the ethical permission for using the shed skin of the snake. S.G.: Figure arrangement, tabulation of the features, part of the discussion rearrangement, reference formatting. N.G., S.K.S., S.D.G., and K.K.C.: Work design, official formalities to get the ethical permission for using the shed skin of the snake and supervision of the whole work with valuable constructing suggestions.

\section{References}

Bing HU, Xiao-zhen Y, Xu-gan WU, Wei-ming T, Yong-xu C ( 2008) Development of Gonad in Different Body Weights of Onchidium struma. Zool Res 29:145-151. https:// doi.org/ 10.3724/SP.J.1141.2008.00145

Costa-Neto, EM (2005) Animal-based medicines: biological prospection and the sustainable use of zootherapeutic resources. An Acad Bras cienc 33.

Dayrat B, Conrad M, Balayan S, White TR., Albrecht C, Golding R, Gomes SR, Harasewych MG, Martins AM de Frias (2011) Phylogenetic relationships and evolution of pulmonate gastropods (Mollusca): New insights from increased taxon sampling. Mol Phylogenet Evol 59:425-437. https://doi.org/10.1016/j.ympev.2011.02.014

Hermann PM, Genereux B, Wildering, WC (2009) Evidence for age-dependent mating strategies in the simultaneous hermaphrodite snail, Lymnaea stagnalis (L.). J Exp Biol 212:3164-3173. 
Janssen R, Baur B (2015) Seasonal effects on egg production and level of paternity in a natural population of a simultaneous hermaphrodite slug. Ecol Evol 5:2916-2928.

https://doi.org/ 10.1002/ece3.1560

Jong-Brink, M De, Schot LP, Schoenmakers HJ, Baergamin Sassen MJM (1981) A biochemical and quantitative electron microscope study on steroidogenesis in ovotestis and digestive gland of the pulmonate slug Lymnaea stagnalis. Gen Comp Endocrinol 45:30-38. https://doi.org/10.1016/00166480(81)90165-9

Koene JM, Montagne-Wajer K, Ter Maat A (2007) Aspects of body size and mate choice in the simultaneously hermaphroditic pond slug Lymnaea stagnalis. Anim Biol 57:247-259. https://doi.org/10.1163/157075607780377983

Lee KS, Lau MWN, Chan BPL, (2004) Wild Animal Trade Monitoring in selected markets in Guangzhou and Shenzhen, South China 2000-2003. AJL Design Ltd., Hong Kong.

Lev E (2003) Traditional healing with animals (zootherapy): medieval to present-day Levantine practice. J Ethnopharmacol 85:107.

Luchtel DL (1972a) Gonadal development and sex determination in pulmonate mollusks. Arion circumscriptus. Zeitschriftfür Zellforschung130:279-301.

Luchtel DL (1972b) Gonadal development and sex determination in pulmonate mollusks. 1. Arion ater rufus and Deroceras reticulatum. Zeitschriftfür Zellforschung 130:302-311.

Luchtel DL, Martin AW, Deyrup-Olsen I, Boer HH (1997) Gastropod: Pulmonata. In: Microscopic Anatomy of Invertebrates, Harrison FW, Koh AJ (eds) New York: Willey Liss, 6B, pp 459-718.

Manthey U, Grossmann W (1997) Amphibien und ReptilienSüdostasiens. - Natur und Tier Verlag, Münster, pp 512.

Michiels NK, Raven-Yoo-Heufes A, Kleine Brockmann K (2003) Sperm trading and sex roles in the hermaphroditic opistobranch sea slug Navanax inermis: eager females or opportunistic males? Biol J Linn Soc 78:105-116. https://doi.org/10.1046/j.1095-8312.2003.00135.x

Mukherjee S, Gupta SCD, Gomes A (2013) Effect of Naja naja Laurenti shed skin extract on estrous cycle, hormone - cytokines profiles, histopathology of ovary and uterus of Swiss albino mice. Indian J Exp Biol 51:235-240.

Mukherjee S, Gupta SCD, Gomes A (2016) Estrous Cycle Cessation Caused via Activating the Apoptotic Pathway by NNSS2 Isolated from Naja naja Shedded Skin. J Toxins 3:1-5. 
Norton CG, Johnson AF, Mueller RL (2008) Relative size influences gender role in the freshwater hermaphroditic slug, Helisoma trivolvis. Behav Ecol 19:1122-1127.

https://doi.org/10.1093/beheco/arn099

Pastisson C, Lacorre I (1996) Fine structure of the germinating cells during the spermiogenesis of Arion rufus (Molluska, Pulmonate Gastropoda). Mol Reprod Dev 43:484-494. doi: 10.1002/(SICl)10982795(199604)43:4<484::AID-MRD11>3.0.C0;2-\#

Ping YX, Sheng-An S, Mei-Ying C (2008) Structure of spermatozoa of Onchidium struma. Acta Zoologica Sinica. 54:373 - 382.

Quattrini D, Lanza B (1964) Osservazioni sulla ovogenesi e sulla spermatogenesi di Vaginulus borellianus (Colosi) Mollusca Gastropoda Soleolifera. Boll Zool 3:541-553.

https://doi.org/10.1080/11250006409441087

Rakshit S, Chaki KK, Sarkar, AK, Misra KK (2005) Cytomorphology of ovotestis of a pulmonate mollusk, Achatina fulica. Proc Zool Soc Calcutta 58:93-104.

Roy S, Chaki KK, Nag TC, Misra KK (2016) Ultrastructure of ovotestis of young and adult of a pulmonate mollusk, Macrochlamys indica Benson, 1832. J Microsc Ultrastruct 4:184-194. https://doi.org/ 10.1016/j.jmau.2016.03.001

Saputra G (2008) Chair IRATA in litt. to Mark Auliya, TRAFFIC Southeast Asia, Malaysia.

Soewu DA (2008) Wild animals in ethnozoological practices among the Yorubas of southwestern Nigeria and the implications for biodiversity conservation. Afr J Agric Res 6:421.

Tomiyama K (1996) Mate choice criteria in a protandrous simultaneously hermaphroditic land snail Achatina fulica (Férussac) (Stylommatophora: Achatinidae). J Moll Stud 62: 101-111.

Zhou B, Ding C, Duan Y, Hui G (2016) The complete mitochondrial genome sequence of Ptyas mucosus. Mitochondrial DNA Part B 1:193-194. doi: 10.1080/23802359.2015.1137848

\section{Figures}



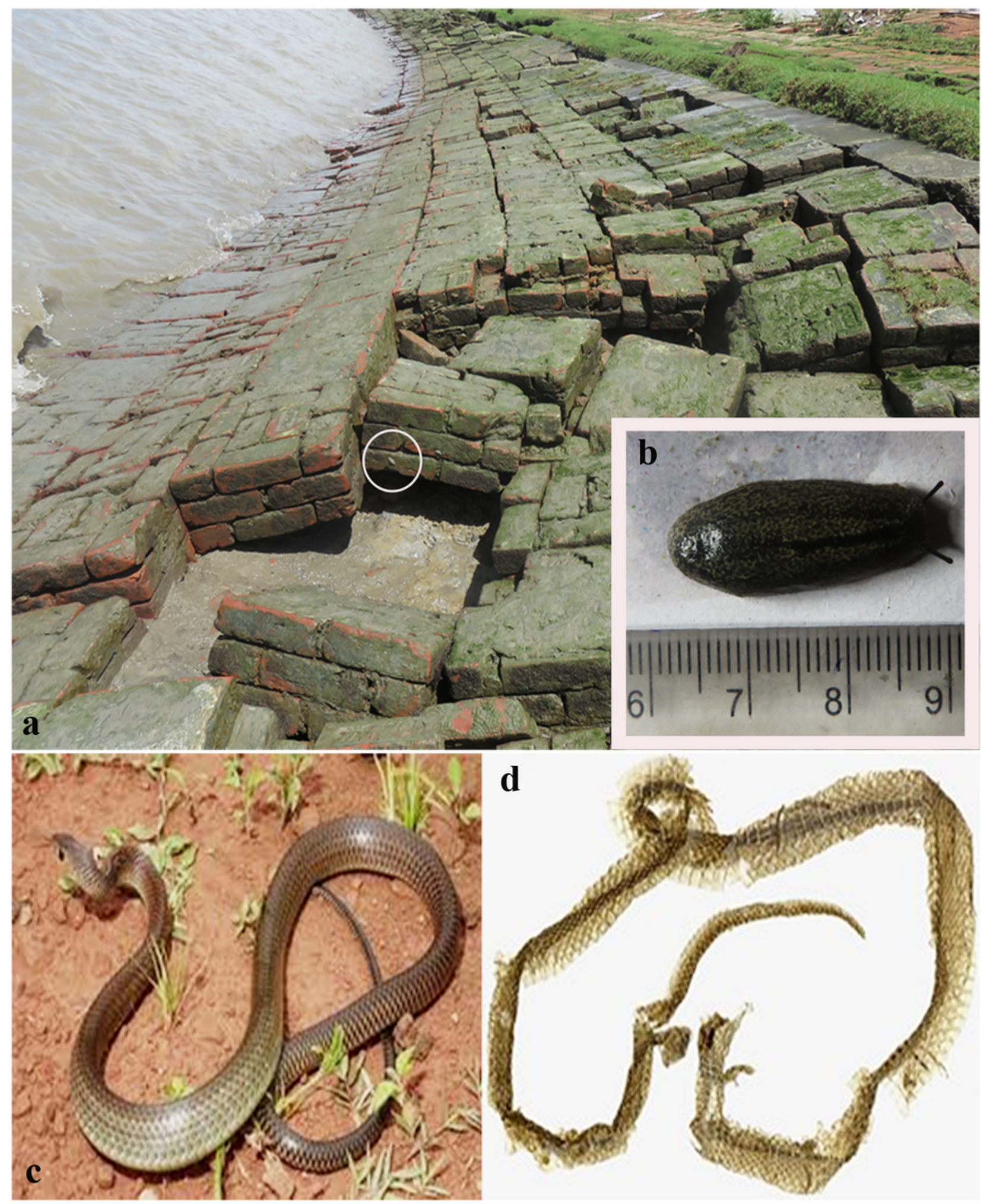

\section{Figure 1}

Sampling area and micro-habitat (white circle) of the Onchidium tigrinum (a). b, An individual slug. The scale was in centimeters. c, A individual non-poisonous snake (Ptyas mucosus). $d$, Shed skin of the Ptyas mucosus. 
Total 160 Onchidium tigrinum ( $1 \pm 0.5 \mathrm{~g}$ body weight $)$ was collected from the bank of Hooghly river and divided into four earthen pots

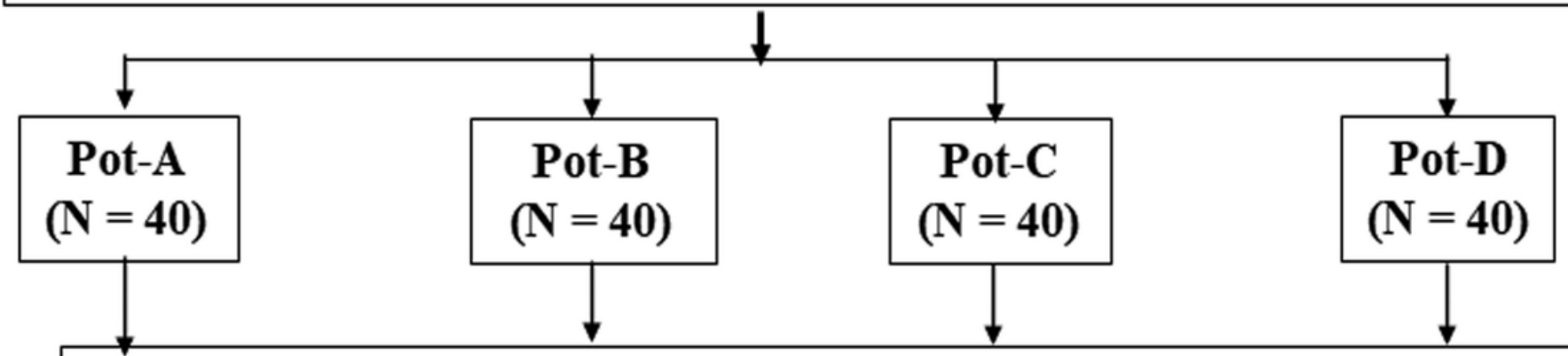

Provide algal flora and river water was sprayed regularly to maintain a humid ambiance in the earthen pots.

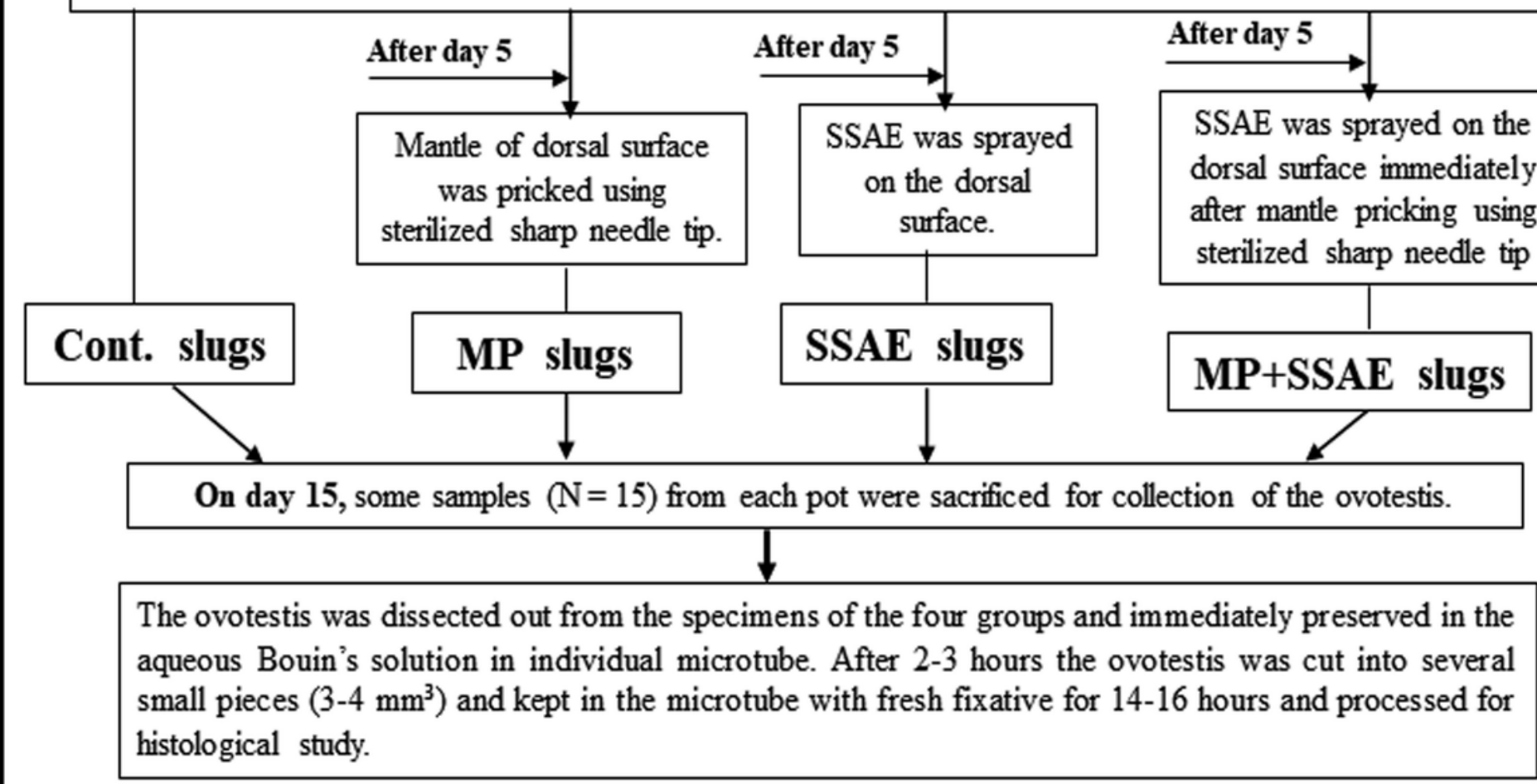

Figure 2

Experimental design of the study. The individuals in the Pot-A were made as control (Cont.) individual. The Pot-B were composed of mantle pricked (MP) individuals to study whether there was any effect of the mantle pricking on gonadal development. The Pot-C included snake shed skin aqueous extract (SSAE) treated individuals without mantle pricking. The Pot-D included SSAE treated on mantle pricked specimens to examine the effect of SSAE on the ovotestis constituents when it mixed directly into the body fluid. 


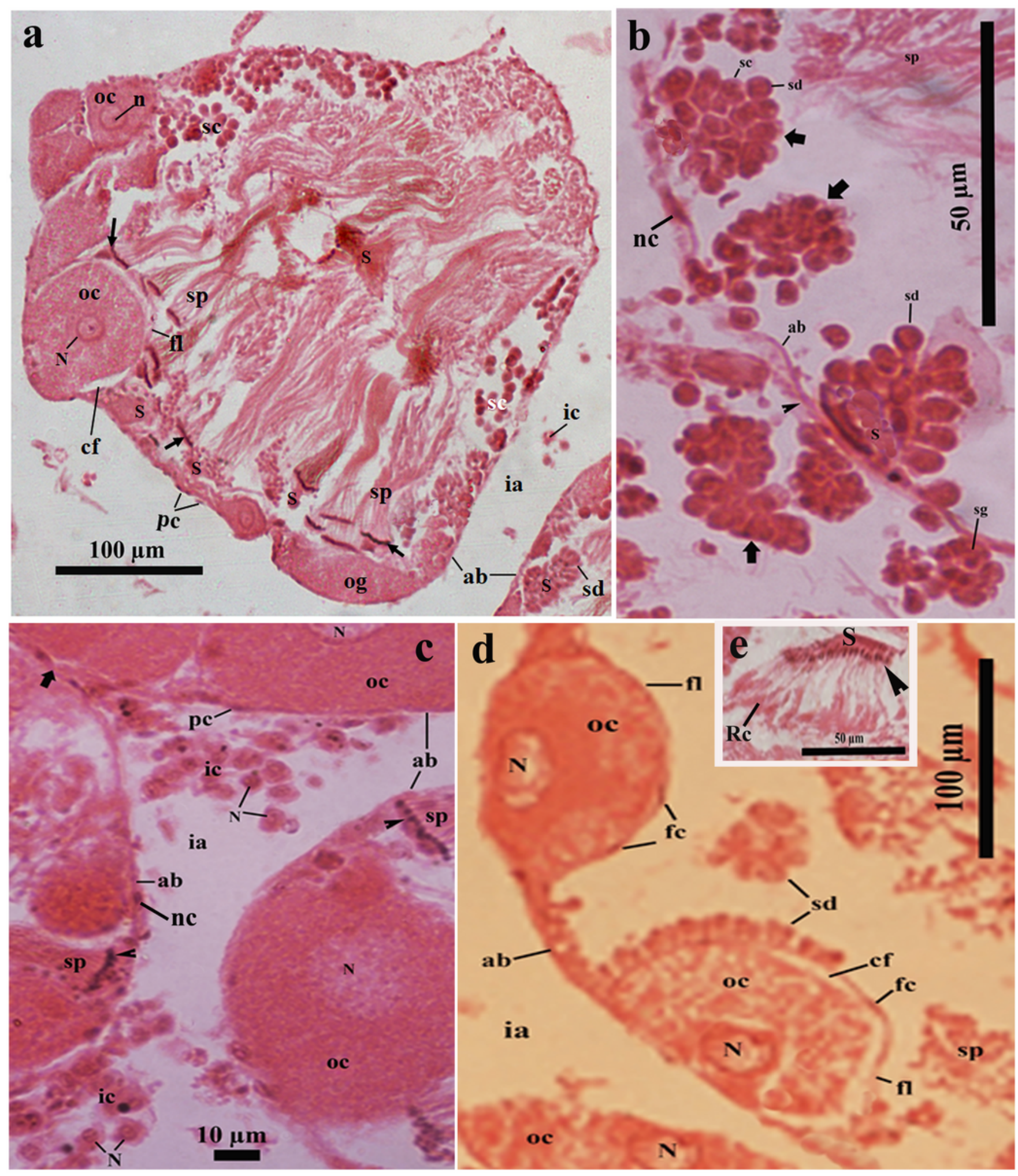

\section{Figure 3}

Light microscopic photomicrograph of a part of the ovotestis of control (in Pot-A) Onchidium tigrinum. a, The acinar space composed of several typical sperm bundles with some developing spermatogenic cells and they were distributed throughout the acinar space. Developing oocytes were restricted to the cortex region of the acini and were surrounded by a distinct follicular layer. Arrow indicates the head of the sperm bundle. b, A portion of the acinus showed the series of cell pyramids (bold arrow) of the 
developing spermatogenic cells. Note the distinct acinar junction (arrow head) of two adjacent acinar boundaries. c, Bunch of the interacinar cells with distinct nucleus in the interacinar zone. Arrow head indicates the nucleus of the sperm bundle, bold arrow indicates the interacinar junction. $d$, Developing oocytes were surrounded by a well-developed follicular layer with distinct follicle cells. e, A bunch of developing spermatids which heads (arrow head) were inserted into a portion of the Sertoli cell (S). Note the residual cytoplasm (Rc) of developing spermatids at the tail region. Abbreviation: ab, acinar boundary; cf, follicular cleft; fl, follicular layer; ia, interacinar zone; ic, interacinar cell; n, nucleolus; N, nucleus; og, oogonium; oc, oocyte, pc, periacinar cell; S, Sertoli cell; sc, spermatocyte; sd, spermatid; sg, spermatogonium; sp, sperm. 


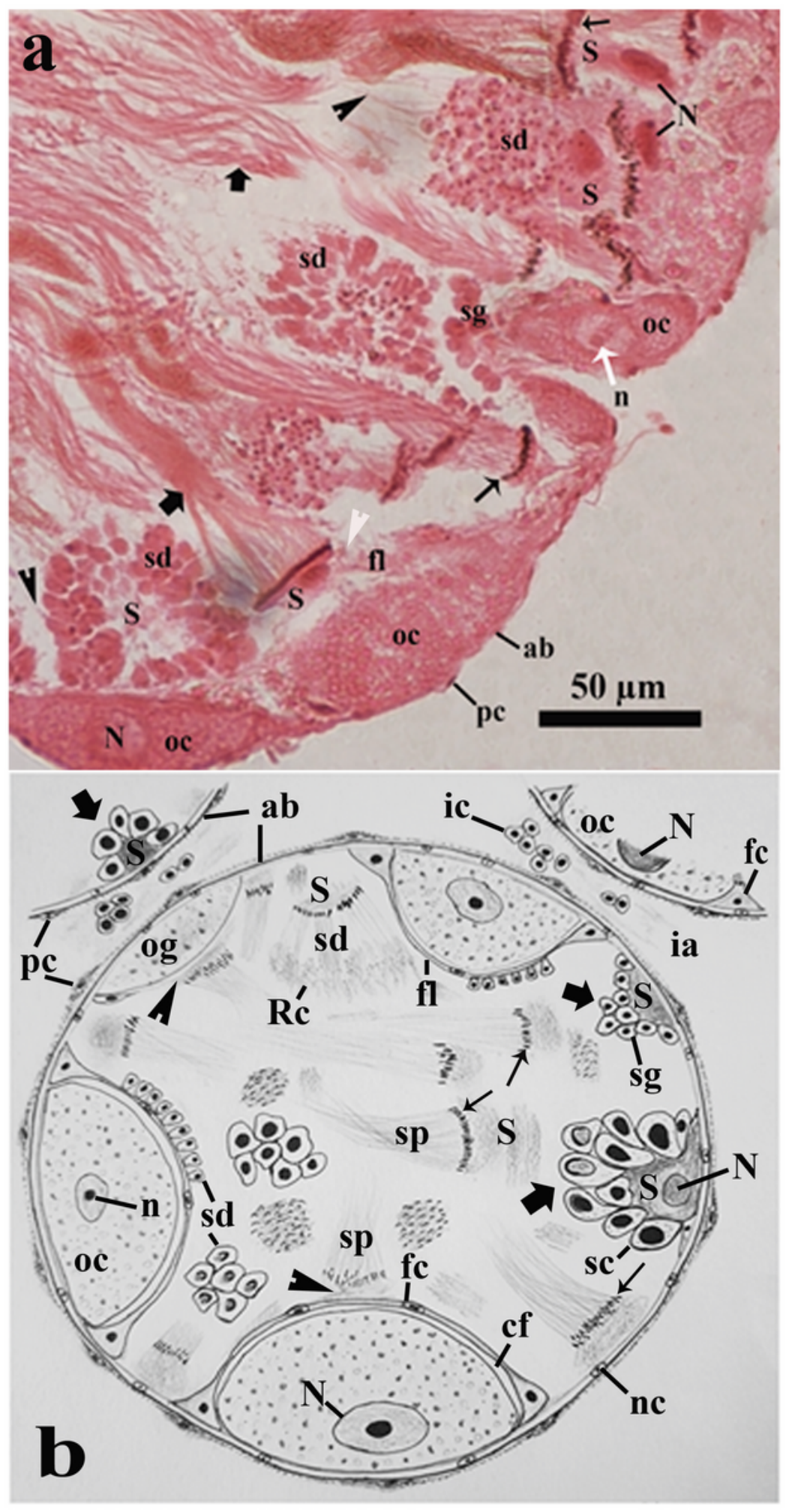

\section{Figure 4}

Photomicrographs of a part of the ovotestis of control (in Pot-A) Onchidium tigrinum. a, A portion of acinar cortex showing developing spermatids with other spermatogenic stages and some developing oocytes. Note the budding tails (arrow head) of the developing spermatids. Bold arrow, sperm bundle; thin arrow, nucleus of sperms in the sperm bundle; white arrow head, intermingled layer of Sertoli cell and follicular layer. b, Schematic representation of an acinus and its allied structures. Abbreviation: ab, acinar 
boundary; cf, follicular cleft; fl, follicular layer; ia, interacinar zone; ic, interacinar cell; $\mathrm{n}$, nucleolus; $\mathrm{N}$, nucleus; og, oogonium; oc, oocyte, pc, periacinar cell; Rc, residual cytoplasm of developing spermatids; S, Sertoli cell; sc, spermatocyte; sd, spermatid; sg, spermatogonium; sp, sperm.

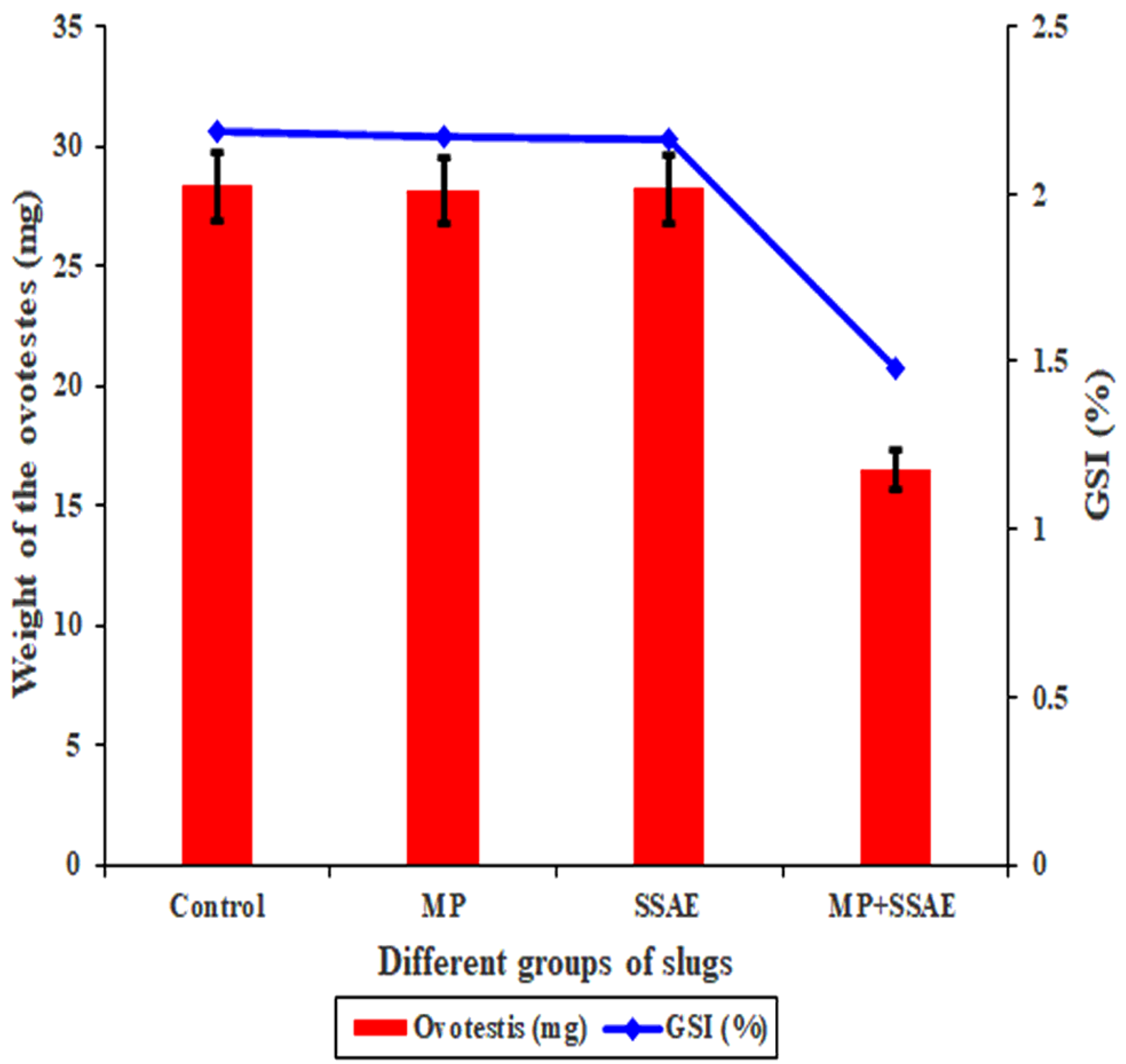

Figure 5

A graphical representation of the relative relationships of the ovotestis and gonado somatic index (GSI) between the control and other three treated groups (MP, SSAE and MP+SSAE) of Onchidium tigrinum. The weight of the ovotestis and the GSI index were almost same in the individuals of the Control, MP and SSAE groups while those were relatively decreased in the slugs of the MP+SSAE group. 

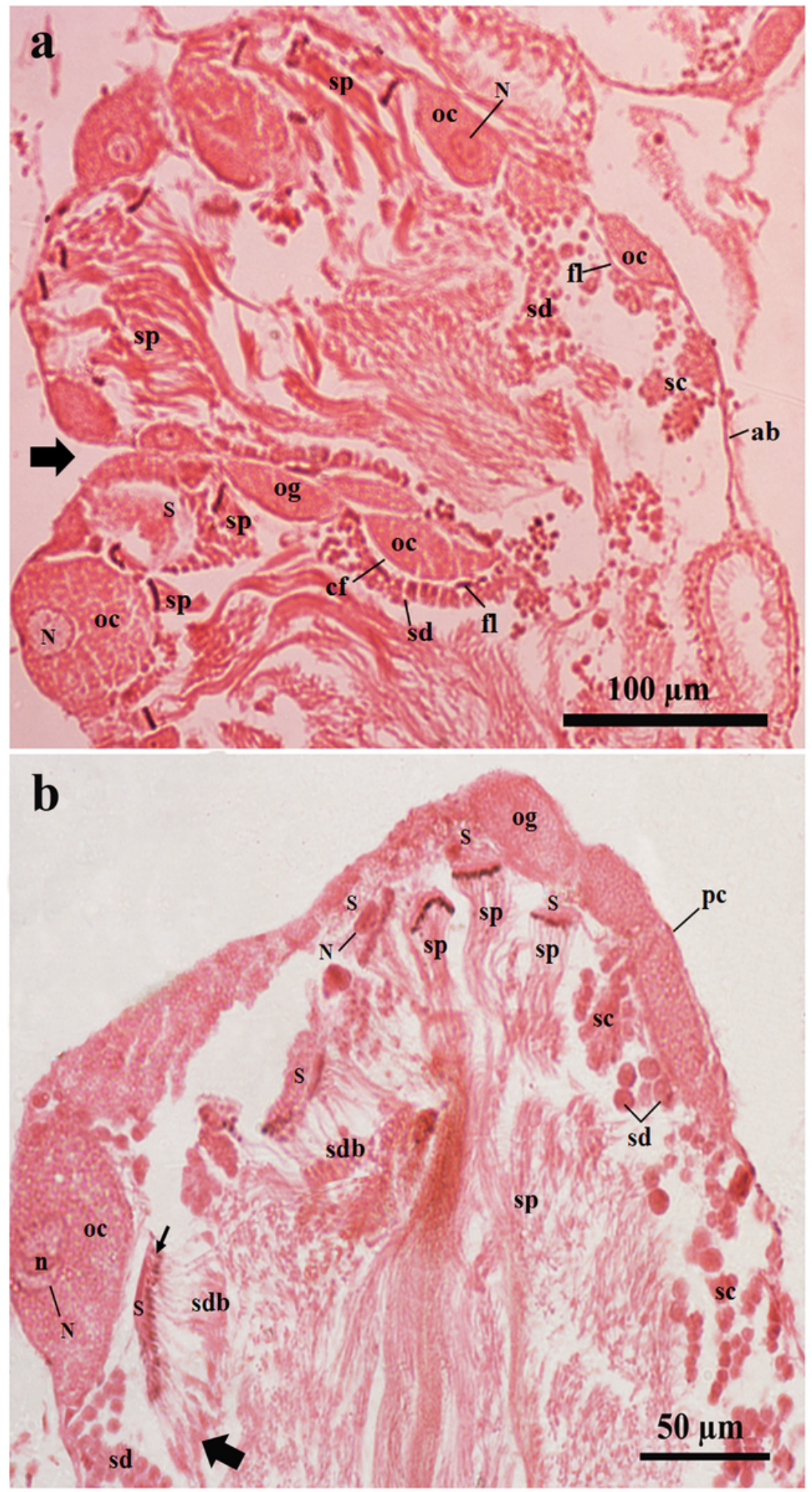

\section{Figure 6}

Photomicrographs of a part of the ovotestis acini of treated Onchidium tigrinum. a, The ovotestis of only mantle pricked slugs (in Pot-B). Bold arrow indicates the acinar junction. b, The ovotestis of the SSAE treated slugs (in Pot-C) without mantle pricked. The characteristics of the acinar components were almost similar between the individuals from both the Pot-B and Pot-C and those were mostly similar as found in the ovotestis of the control individuals (in Pot-A). Note the residual cytoplasmic materials in the 
developing spermatids were gradually moved toward the tail region (bold arrow) of these elongated cells. Arrow indicates the head of the developing spermatid bundle. Abbreviation: ab, acinar boundary; cf, follicular cleft; fl, follicular layer; ia, interacinar zone; ic, interacinar cell; n, nucleolus; N, nucleus; og, oogonium; oc, oocyte, pc, periacinar cell; $\mathrm{S}$, Sertoli cell; sc, spermatocyte; sd, spermatid; sdb, spermatid bundle; sp, sperm.

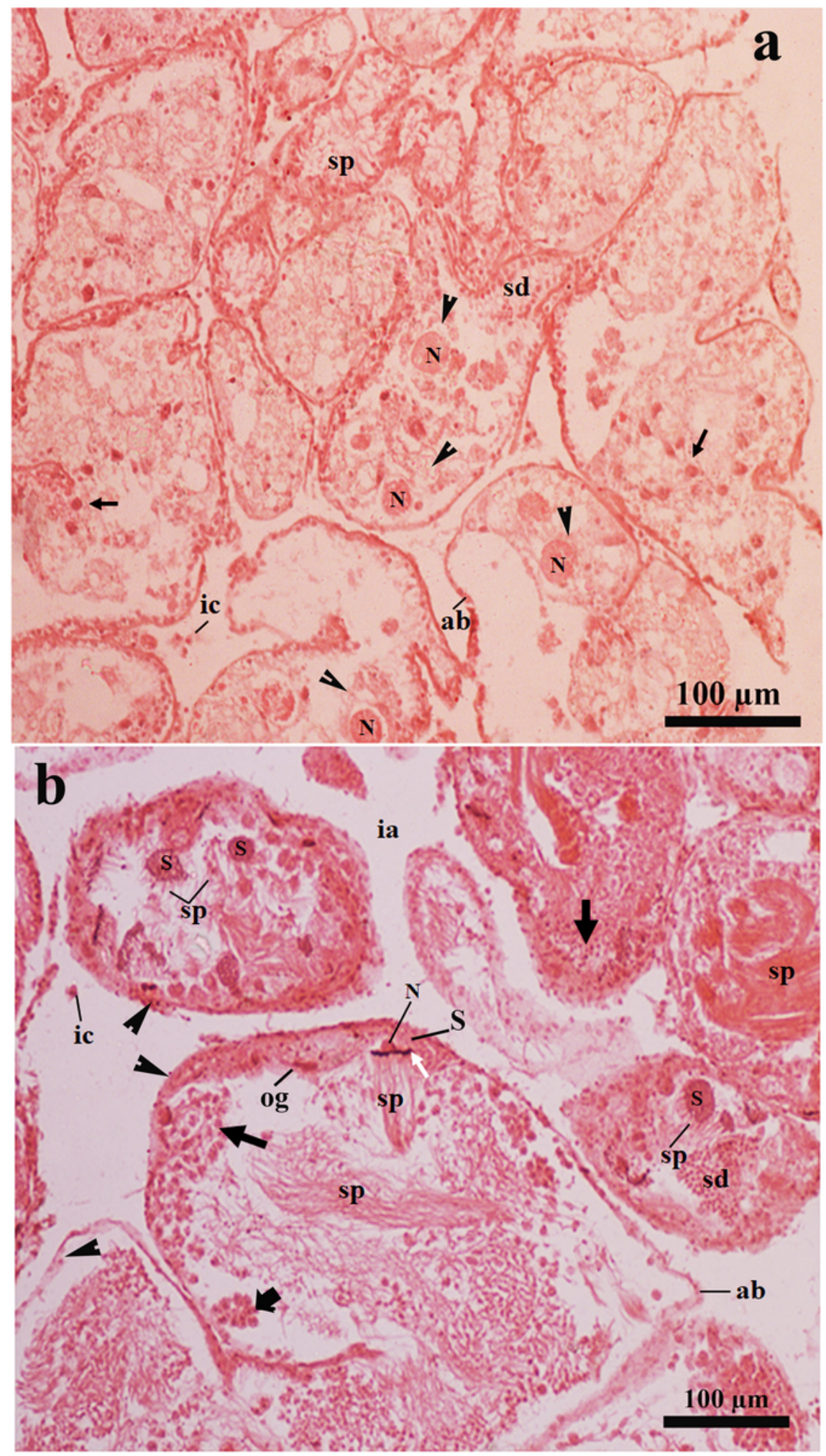

Figure 7 
Photomicrographs of a part of the ovotestis of the SSAE treated-mantle pricked Onchidium tigrinum (in Pot-D). The overall structural arrangement of the acinar constituents was characteristically hampered in most of the acini which including very thin granulated acinar boundary. a, The cell membrane of the developing oocytes (arrow head) were damaged and the nucleus $(\mathrm{N})$ of the corresponding cells were free without cytoplasm. Arrow indicates the cytoplasm free nucleus of the developing spermatogenic cells. $b$, The intimate association between the Sertoli cells and the developing spermatogenic cells are characteristically hampered. Typical spiral pattern at the tail region of the sperm bundle was changed to a hazy structure. Black arrow indicates cytoplasm free nucleus of spermatogenic cells in various developmental stages. White arrow indicates the head of the sperm bundle. Note the bare nucleus of the Sertoli cell. Cell pyramid (bold arrow) was smaller in size and loosely attached to the acinar boundary, which was granulated with numerous small, circular granules (arrow heads). Most of the interacinar zone were free from the interacinar cells. Abbreviation: ab, acinar boundary; cf, follicular cleft; fl, follicular layer; ia, interacinar zone; ic, interacinar cell; N, nucleus; og, oogonium; pc, periacinar cell; S, Sertoli cell; sc, spermatocyte; sd, spermatid; sp, sperm. 


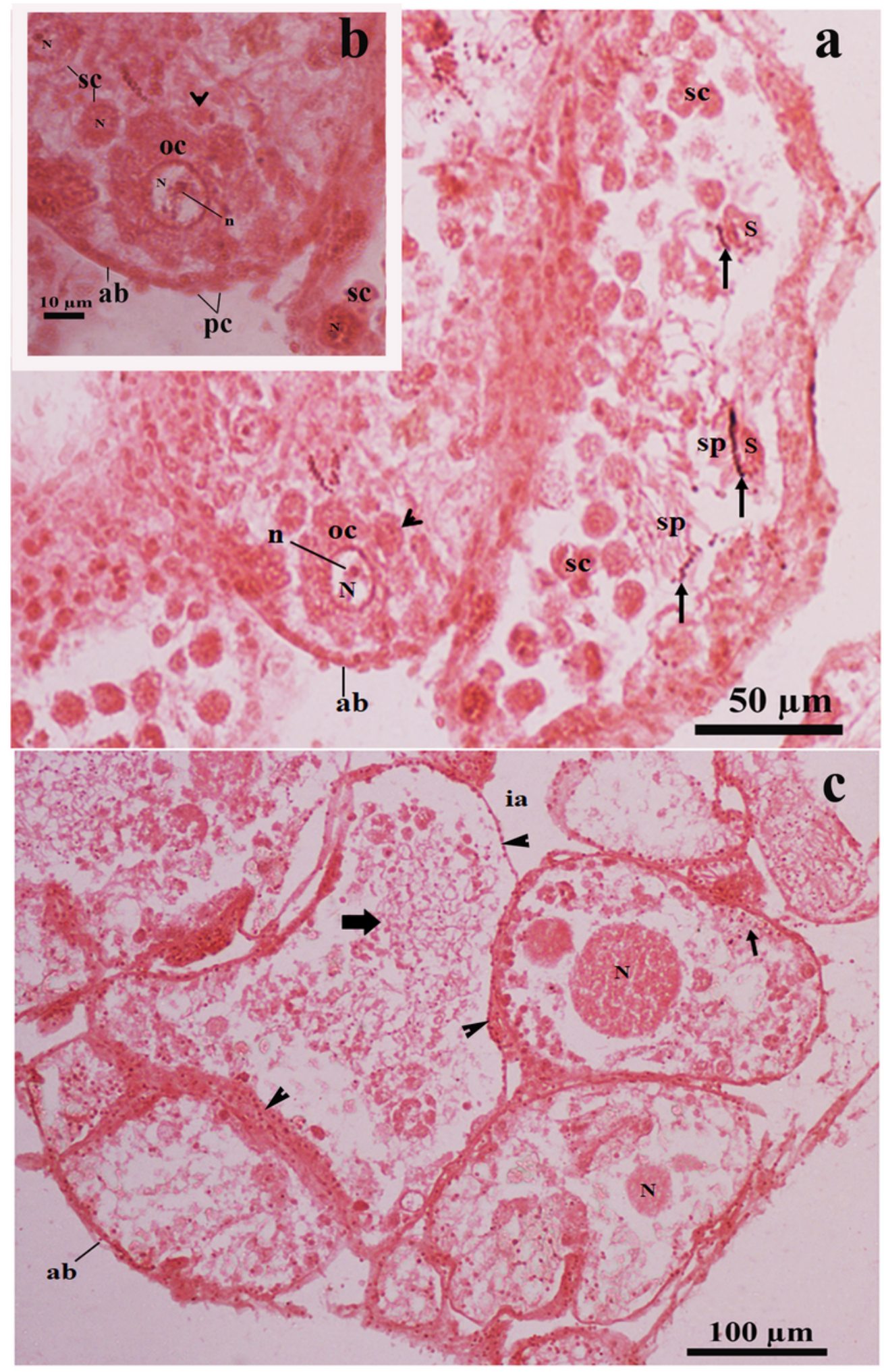

\section{Figure 8}

Light microscopic photomicrographs of a part of the ovotestis of the SSAE treated-mantle pricked Onchidium tigrinum (in Pot-D). a, The acinus was composed of characteristically distorted oocyte without covering of the follicular layer. The oolemma bulges outward and separated as small ooplasmic blebs (arrow head) from the oocyte. These blebs included a portion of the ooplasm into them. Arrow indicates the head of the developing sperms. The sperm heads were very loosely adhered to the residual part of the 
Sertoli cell. b, Enlarged view of the distorted oocyte of the figure A, showed distinct ooplasmic bleb (arrow head) was separated from the oocyte. c, Overall acinar constituents in most of the acini were drastically changed. The cytoskeleton of the developing oocytes in most of the acini were damaged. The cytoplasm free nucleus of the oocyte was moved toward the acinar lumen in many acini. Thin arrow indicates nuclear materials of developing spermatogenic cells. Bold arrow indicates the hazy appearance of the sperm tails. Arrow head indicates granulated acinar boundaries.

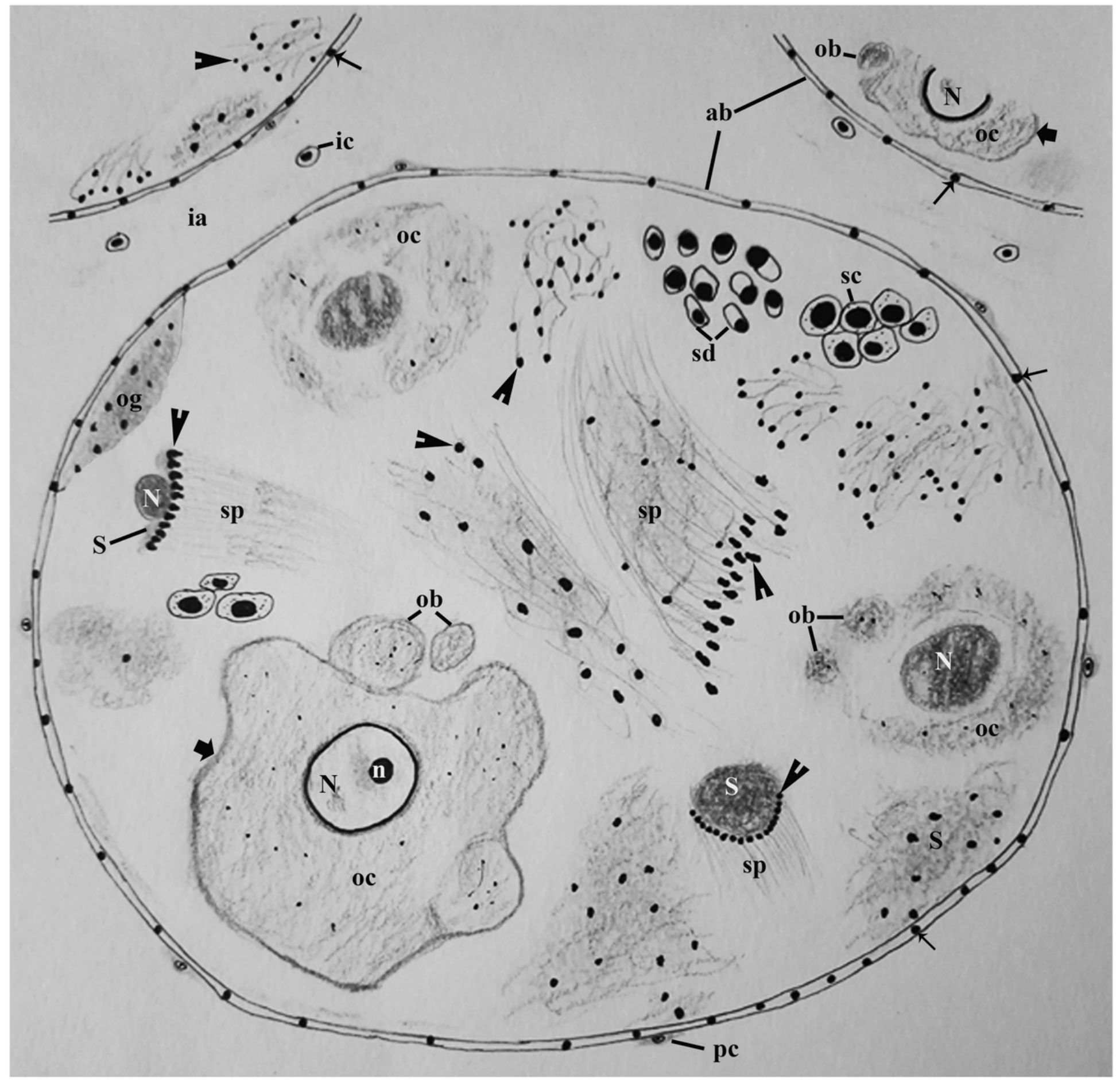

Figure 9 
Schematic representation of an acinus in the ovotestis of MP+SSAE treated Onchidium tigrinum. Overall ornamentations of the acinar constituents were drastically deteriorated with granulated acinar boundary. The oocyte lacks the follicular layer. Note the thickening of nuclear membrane of the oocyte nucleus. The oolemma bulges outward and separated as small ooplasmic blebs (ob) from the oocyte. Note the bare nucleus of the Sertoli cell. Sperms in the sperm bundle contained bead-like heads. Abbreviation: $a b$, acinar boundary; cf, follicular cleft; fl, follicular layer; ia, interacinar zone; ic, interacinar cell; $n$, nucleolus; $\mathrm{N}$, nucleus; og, oogonium; oc, oocyte, pc, periacinar cell; S, Sertoli cell; sc, spermatocyte; sd, spermatid; sg, spermatogonium; sp, sperm. Thin arrow, granule in the acinar boundary; bold arrow, oolemma of oocyte, arrow head, sperm head. 

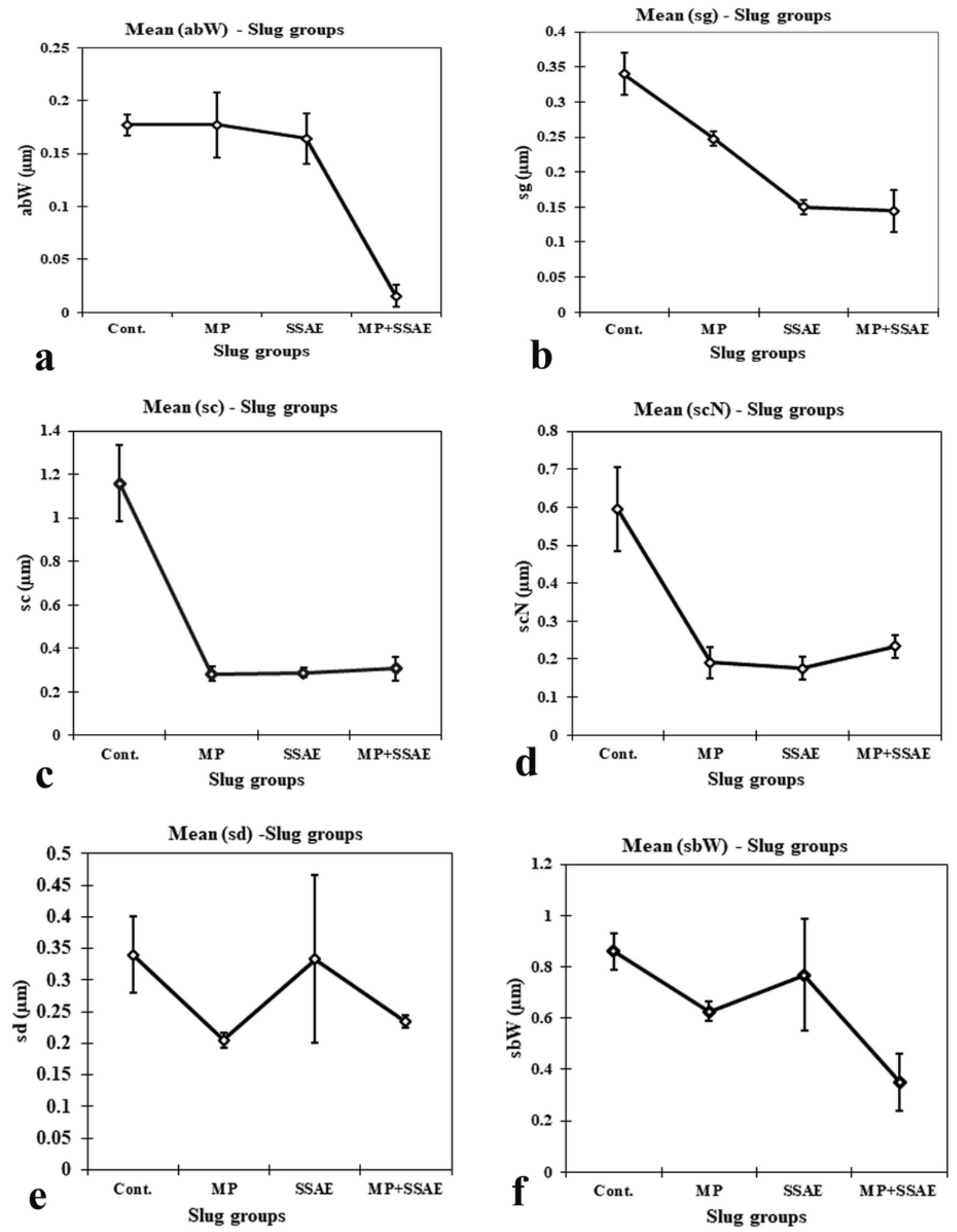

\section{Figure 10}

Relative developmental variations of some acinar constituents between control and treated Onchidium tigrinum. a, width of acinar boundary (abW); b, diameter of spermatogonium (sg); c, diameter of spermatocyte (sc); d, diameter of spermatocyte nucleus (scN); e, diameter of spermatid (sd); f, width of sperm bundle (sbW). Abbreviation: Cont., control individuals; MP, mantle pricked individuals; SSAE, only 

treatment on mantle pricked individuals.
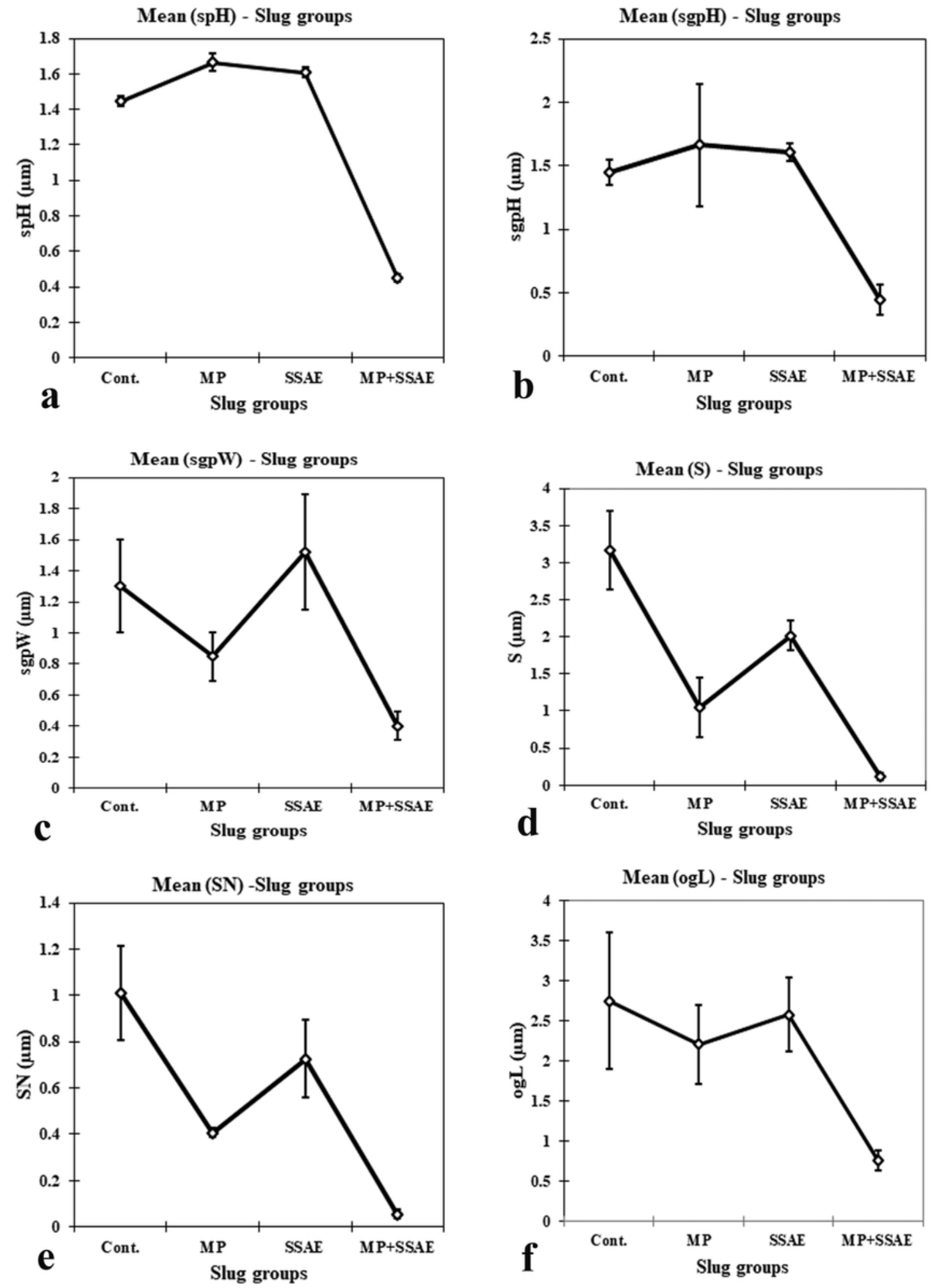

Figure 11

Relative developmental variations of some acinar constituents between control and treated Onchidium tigrinum. a, Length of sperm head (spH); b, height of spermatogenic cell pyramid (sgpH); c, width of spermatogenic cell pyramid (sgpW); d, diameter of Sertoli cell (S); E, diameter of Sertoli cell nucleus (SN); 
$\mathrm{f}$, length of elongated oogonium (ogL). Abbreviation: Cont., control individuals; MP, mantle pricked individuals; SSAE, only snake shed skin aqueous extract treated individuals; MP+SSAE, snake shed skin aqueous extract treatment on mantle pricked individuals.
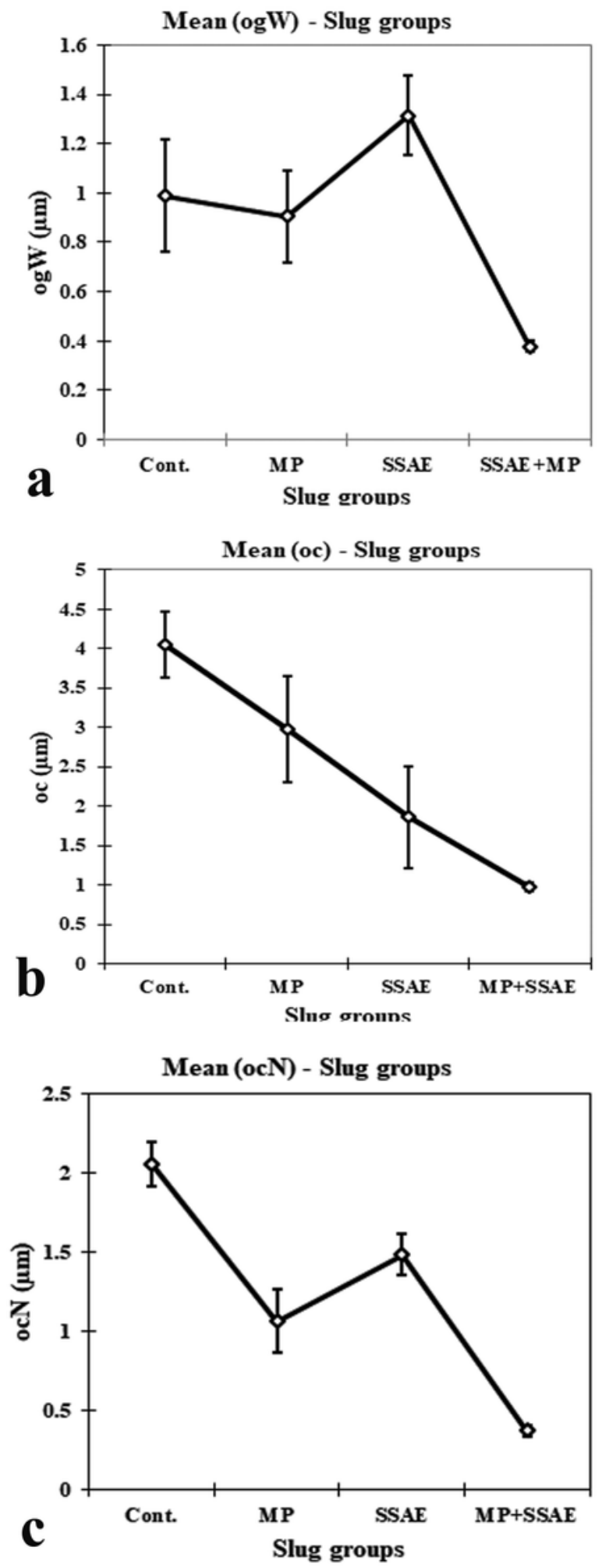

Figure 12

Relative developmental variations of some acinar constituents between control and treated Onchidium tigrinum. a, width of elongated oogonium (ogW); b, diameter of oocyte (oc); c, diameter of oocyte nucleus 
(ocN). Abbreviation: Cont., control individuals; MP, mantle pricked individuals; SSAE, only snake shed skin aqueous extract treated individuals; MP+SSAE, snake shed skin aqueous extract treatment on mantle pricked individuals.

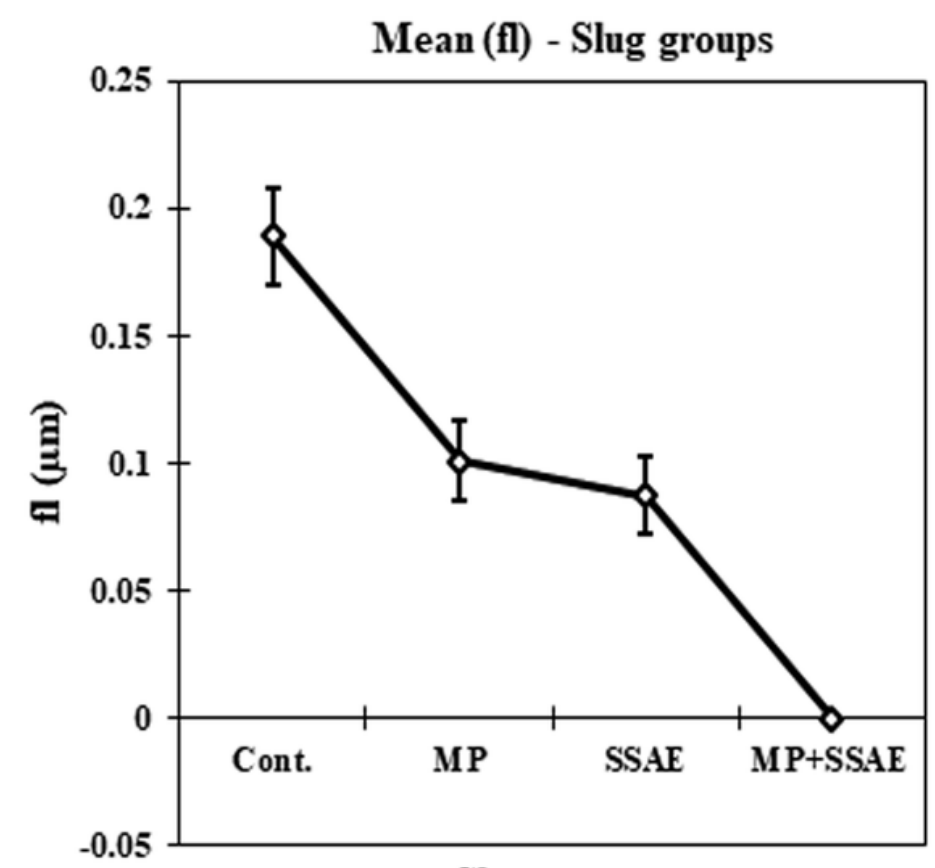

a

Slug groups
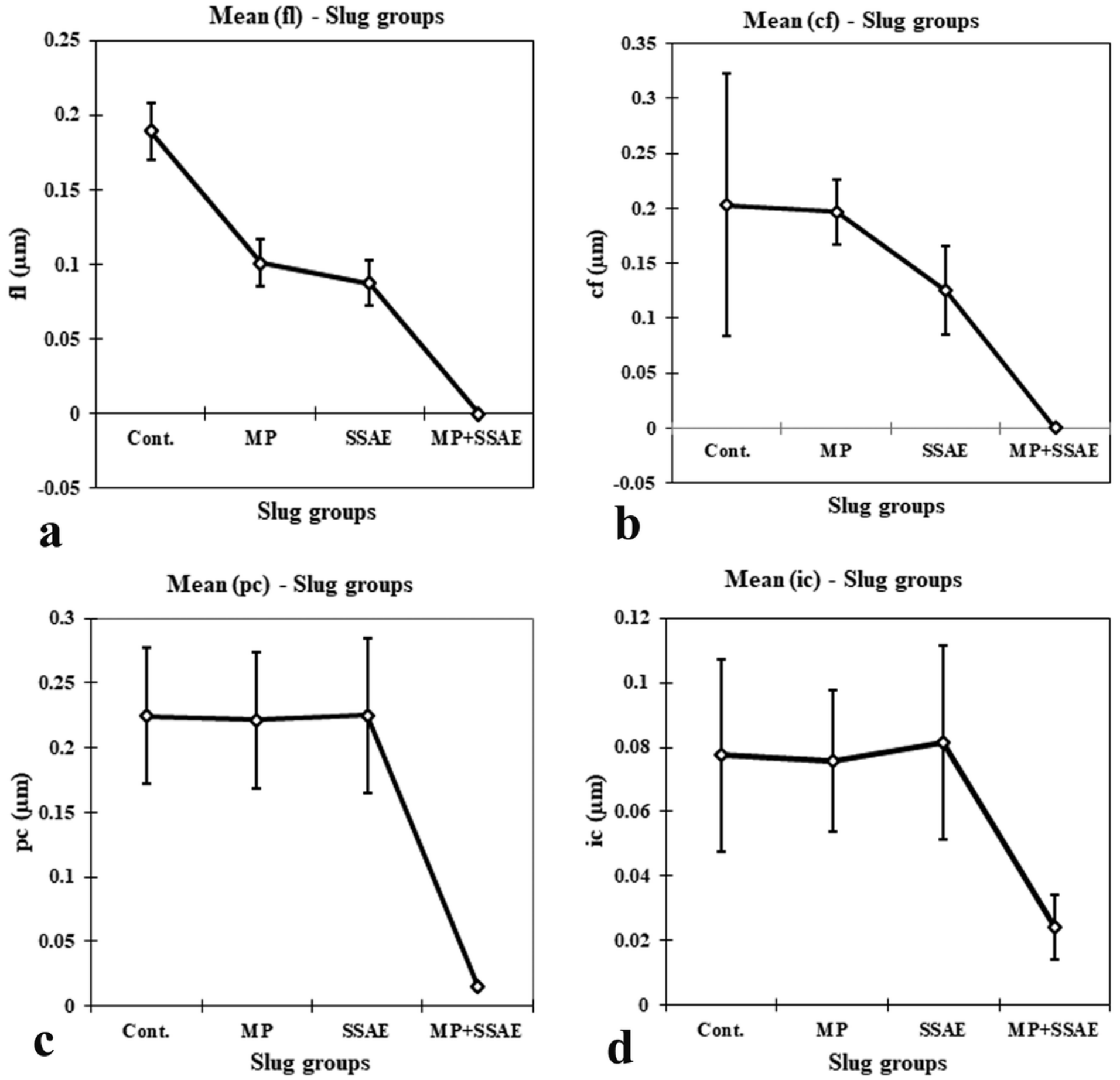

b

Slug groups

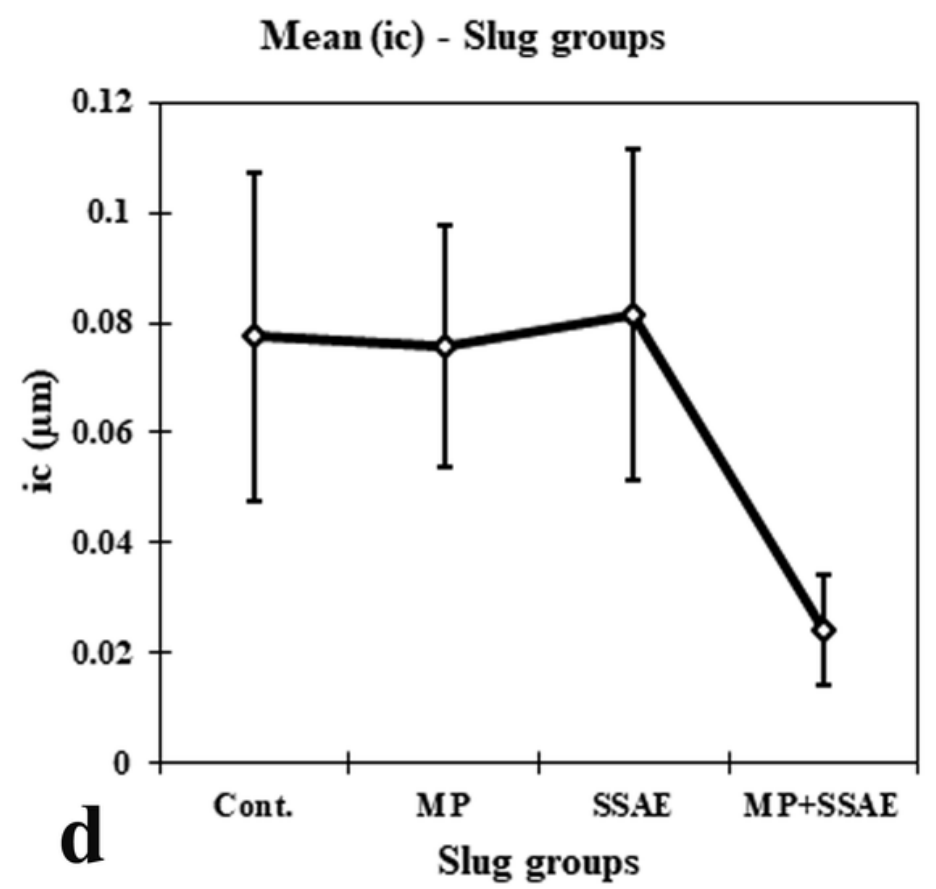

Figure 13

Relative developmental variations of some acinar constituents between control and treated Onchidium tigrinum. a, width of follicular layer (fl); b, width of follicular cleft (cf); c, length of periacinar cell (pc); d, diameter of interacinar cell (ic). Abbreviation: Cont., control individuals; MP, mantle pricked individuals; 
SSAE, only snake shed skin aqueous extract treated individuals; MP+SSAE, snake shed skin aqueous extract treatment on mantle pricked individuals. 